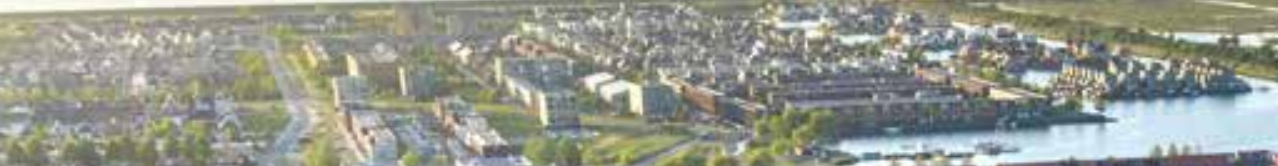

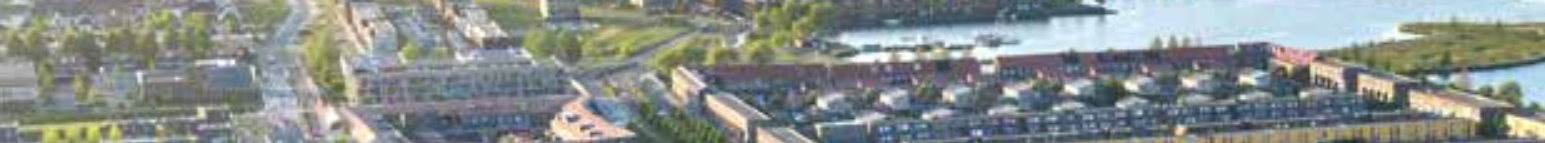

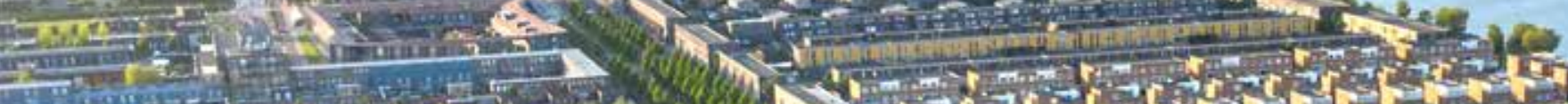

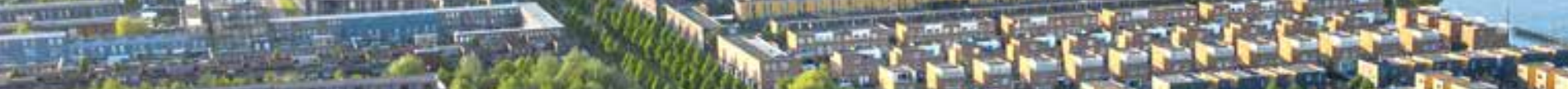

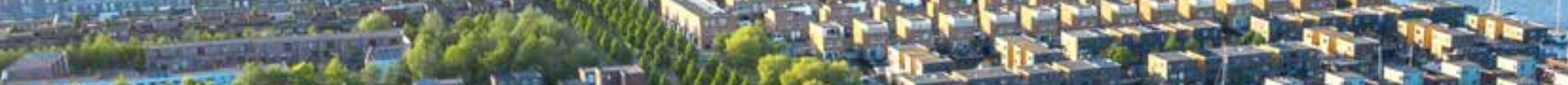
S.

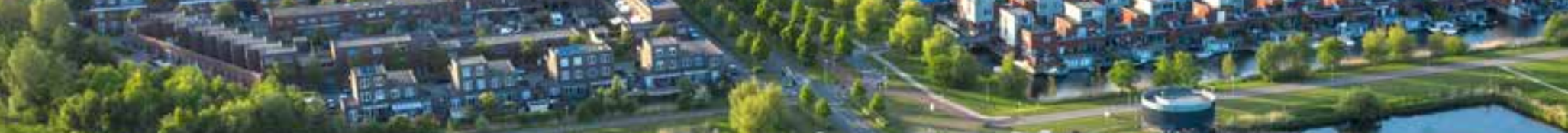
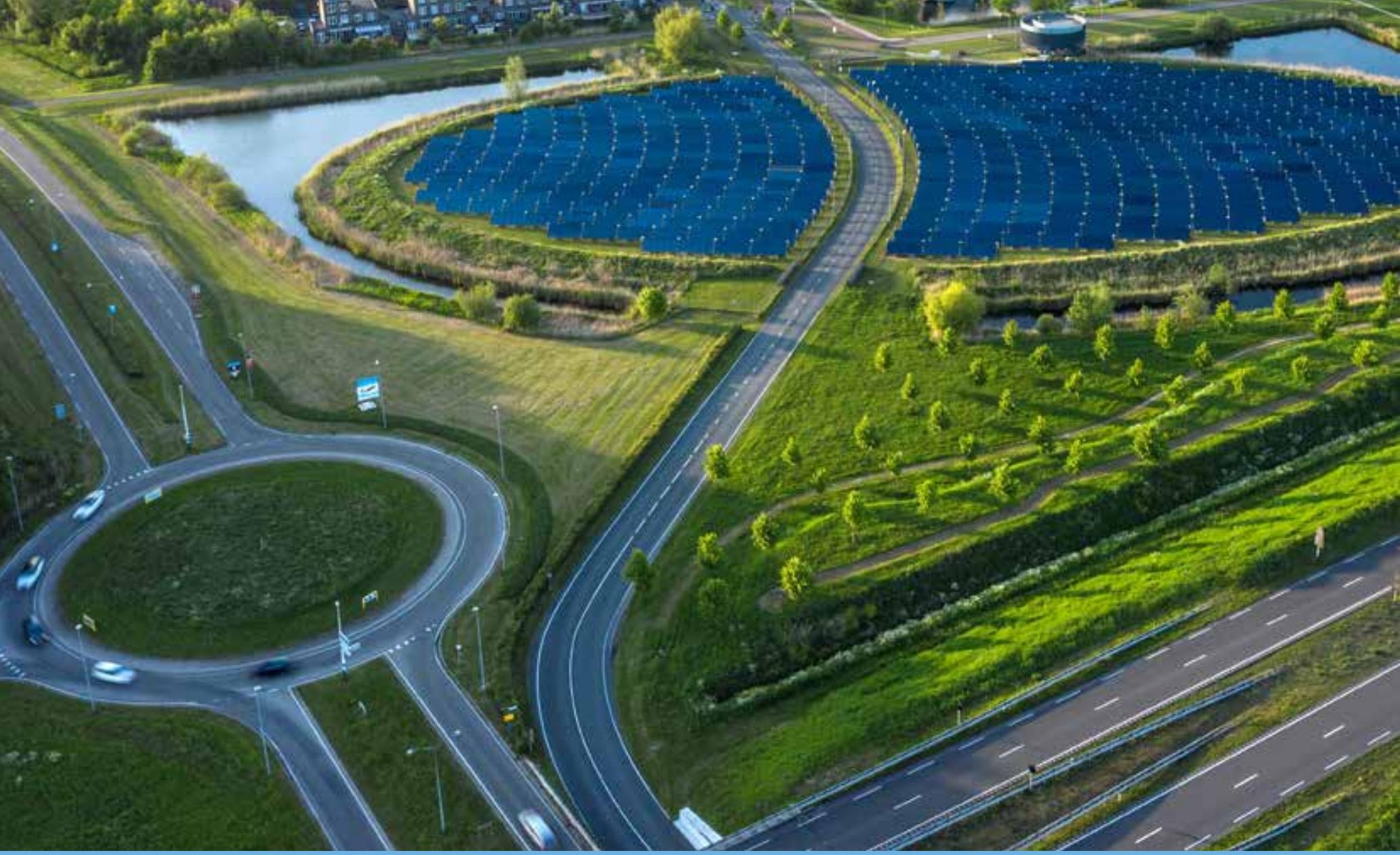

\title{
De bijdrage van de vastgoedsector aan een natuurinclusieve leefomgeving
}

Achtergrondrapport

Marijke Dijkshoorn-Dekker, Thomas Mattijssen, Mariët van Haaster-de Winter, Harry Kortstee,

Nico Polman

WAGENINGEN

UNIVERSITY \& RESEARCH 



\section{De bijdrage van de vastgoedsector aan een natuurinclusieve leefomgeving}

Achtergrondrapport

Marijke Dijkshoorn-Dekker, Thomas Mattijssen, Mariët van Haaster-de Winter, Harry Kortstee, Nico Polman

Dit onderzoek is uitgevoerd door Wageningen Economic Research in opdracht van en gefinancierd door het ministerie van Landbouw, Natuur en Voedselkwaliteit in het kader van de kennisbasisgelden, thema 'NatureInclusive Transitions.' (projectnummer KB-36-005-004)

Wageningen Economic Research

Wageningen, mei 2020

RAPPORT

2020-013b

ISBN 978-94-6395-400-6 
Marijke Dijkshoorn-Dekker, Thomas Mattijssen, Mariet van Haaster-de Winter, Harry Kortstee en Nico Polman, 2020. De bijdrage van de vastgoedsector aan een natuurinclusieve leefomgeving; Achtergrondrapport. Wageningen, Wageningen Economic Research, Rapport 2020-013b. 38 blz.; 4 fig.; 1 tab.; 114 ref.

Met dank aan Sabine van Rooij en Eveline Steingröver (Wageningen Environmental Research) voor hun bijdrage aan het casestudy-onderzoek.

De vastgoedsector kan een belangrijke rol spelen in een bredere transitie naar een natuurinclusieve leefomgeving die sociaal, economisch en ecologisch veerkrachtig is. In de huidige praktijk legt groen het vaak af tegen concurrerende ruimteclaims. Met dit project zoeken we naar aanknopingen om beweging in de vastgoedsector te creëren naar meer groen in een stedelijke omgeving. Dat doen we door het ontwikkelen van een transitieaanpak voor natuurinclusief ondernemen. In deze aanpak wordt gekeken naar de vastgoedsector in brede zin (zoals grondbezitters, investeerders, architecten, vastgoedeigenaren en projectontwikkelaars).

The real estate industry can play a key role in a wider transition to a nature-inclusive living environment that offers social, economic and ecological resilience. In this research, we look explicitly for a pro-active green contribution from the industry to the liveability and resilience of urban areas. To set such practices in motion, we are looking for points of departure in the considerations being made by different actors in the real estate industry. We do this by developing a transition approach for nature-inclusive enterprise. This approach looks at the real estate industry more widely, including landowners, investors, architects, property owners and project developers.

Trefwoorden: transitie, vastgoedsector, natuurinclusief, stedelijk groen

Dit rapport is gratis te downloaden op https://doi.org/10.18174/521455 of op www. wur. nl/economicresearch (onder Wageningen Economic Research publicaties).

(C) 2020 Wageningen Economic Research

Postbus 29703, 2502 LS Den Haag, T 07033583 30, E communications.ssg@wur.nl, www.wur.nl/economic-research. Wageningen Economic Research is onderdeel van Wageningen University \& Research.

\section{(cc) BY-NC}

Dit werk valt onder een Creative Commons Naamsvermelding-Niet Commercieel 4.0 Internationaallicentie.

(C) Wageningen Economic Research, onderdeel van Stichting Wageningen Research, 2020

De gebruiker mag het werk kopiëren, verspreiden en doorgeven en afgeleide werken maken. Materiaal van derden waarvan in het werk gebruik is gemaakt en waarop intellectuele eigendomsrechten berusten, mogen niet zonder voorafgaande toestemming van derden gebruikt worden. De gebruiker dient bij het werk de door de maker of de licentiegever aangegeven naam te vermelden, maar niet zodanig dat de indruk gewekt wordt dat zij daarmee instemmen met het werk van de gebruiker of het gebruik van het werk. De gebruiker mag het werk niet voor commerciële doeleinden gebruiken.

Wageningen Economic Research aanvaardt geen aansprakelijkheid voor eventuele schade voortvloeiend uit het gebruik van de resultaten van dit onderzoek of de toepassing van de adviezen.

Wageningen Economic Research is ISO 9001:2015 gecertificeerd.

Wageningen Economic Research Rapport 2020-013b | Projectcode 2282700449

Foto omslag: Shutterstock 


\section{Inhoud}

Samenvatting $\quad 5$

$\begin{array}{ll}\text { Summary } & 7\end{array}$

1

$\begin{array}{ll}\text { Inleiding } & \mathbf{8}\end{array}$

1.1 Een aanpak voor natuurinclusief ondernemen ontbreekt $\quad 8$

1.2 Gelaagde aanpak 9

$\begin{array}{lll}1.3 & \text { Leeswijzer } & 13\end{array}$

2

$\begin{array}{ll}\text { Conceptueel kader } & 14\end{array}$

$2.1 \quad$ Bouwstenen voor het conceptueel kader 14

2.1.1 Een natuurinclusieve vastgoedsector vergt brede verandering $\quad 14$

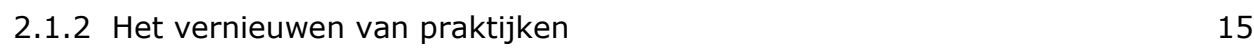

2.1.3 Veranderend gedrag in diverse praktijken 16

$\begin{array}{lll}2.2 & \text { Conceptueel kader natuurinclusief ondernemen } & 17\end{array}$

3 Rol van de vastgoedsector in het internationale perspectief $\quad 20$

3.1 Maatschappelijke betrokkenheid bij groen in de stad 20

$\begin{array}{lll}3.2 & \text { Functie van groen in de stad } & 21\end{array}$

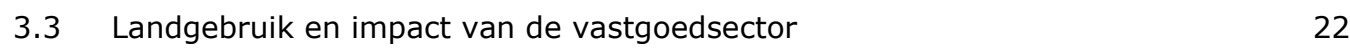

3.4 De wereld van de projectontwikkelaar: bestaande praktijken, afwegingen en incentives 23

$\begin{array}{lll}3.5 & \text { Investering in en financiering van groen } & 24\end{array}$

3.6 De integratie van groen en grijs: een zoektocht naar synergieën 25

$\begin{array}{lll}3.7 & \text { Planning en governance } & 26\end{array}$

$\begin{array}{lll}3.8 & \text { Het perspectief van de bewoner als gebruiker } & 27\end{array}$

$\begin{array}{ll}\text { Literatuur en websites } & \mathbf{3 0}\end{array}$

$\begin{array}{lll}\text { Bijlage } 1 & \text { Literatuuronderzoek } & 36\end{array}$ 



\section{Samenvatting}

Natuur heeft een belangrijke functie voor de leefbaarheid van steden: stedelijk groen draagt bij aan gezondheid en welzijn, een aangename woonomgeving voor stedelingen en een positief vestigingsklimaat voor bedrijven. Ook voor de biodiversiteit en het milieu is de aanwezigheid van voldoende stedelijk groen van groot belang, bijvoorbeeld om wateroverlast tegen te gaan en te zorgen voor een goed leefmilieu voor diverse diersoorten. Toch legt groen het in de praktijk vaak af tegen concurrerende ruimteclaims. Dit kan een grote impact hebben op de leefomgeving van mensen die in de stad wonen en werken.

Dit project kijkt naar de invloed van de vastgoedsector op stedelijk groen. De vastgoedsector kan een belangrijke rol spelen in een bredere transitie naar een natuurinclusieve leefomgeving die sociaal, economisch en ecologisch veerkrachtig is. Met dit onderzoek zoeken we expliciet naar een actieve groene bijdrage van deze sector aan de leefbaarheid ${ }^{1}$ en veerkracht ${ }^{2}$ van steden. Dat doen we door het ontwikkelen van een transitie-aanpak voor natuurinclusief ondernemen. In deze aanpak wordt gekeken naar de vastgoedsector in brede zin (zoals grondbezitters, investeerders, architecten, vastgoedeigenaren en projectontwikkelaars).

Ten behoeve van deze aanpak presenteren wij in dit rapport een raamwerk waarbij we ons hebben laten inspireren door drie wetenschappelijke theorieën: de transitietheorie (transition theory), de theorie van de praktijk (theory of practice) en de theorie van gepland gedrag (theory of planned behaviour). De transitietheorie gebruiken we om het proces van verandering van praktijken te beschrijven op de lange termijn. Bij de theorie van de praktijk gaat het bijvoorbeeld over de handelingen die nodig zijn om van bouwmaterialen een woonhuis te bouwen. En met behulp van de theorie van gepland gedrag kijken we naar factoren die praktijken beïnvloeden en hoe actoren door bestaande praktijken worden beïnvloed. Een natuurinclusieve sector vergt een brede verandering, waarbij verandering plaatsvindt via het vernieuwen van een breed scala aan praktijken. Om deze praktijken in beweging te kunnen brengen, zoeken we naar aanknopingspunten in de afwegingen die diverse actoren in de vastgoedsector maken

De inhoudelijke studie van wetenschappelijke literatuur rondom natuurinclusief bouwen leidt uiteindelijk tot een selectie en analyse van 86 wetenschappelijke publicaties. Hoewel natuur geen dominant thema is in de vastgoedliteratuur (het gaat veel vaker over milieuaspecten), is er dus wel degelijk wetenschappelijke aandacht voor het onderwerp. Hierbij onderscheiden we acht inhoudelijke 'clusters' die van belang zijn binnen de wetenschappelijke literatuur:

1. De betrokkenheid van vastgoedpartijen bij groen in de stad

2. De functie van groen in de stad en de rol van vastgoedpraktijken hierbij

3. Stedelijk ruimtegebruik en de impact van de vastgoedsector

4. De wereld van de projectontwikkelaar: praktijken, afwegingen en incentives

5. Investering en financiering van groen in de stad

6. Planning en governance: sturingsinstrumenten voor een groene stad

7. Het perspectief van de bewoner (gebruiker)

8. De integratie van groen en grijs: een zoektocht naar synergieën

Voor elk van deze clusters benoemen we in deze rapportage de bevindingen uit relevante artikelen.

Uiteindelijk is de rol van groen op de (toekomstige) grijze agenda een belangrijke factor voor de toekomstige biodiversiteit en natuur in de stad. Het is de vraag of die agenda van kleur zal veranderen. De aandacht vanuit de literatuur lijkt enigszins groeiende, maar wanneer men het heeft over 'groen' in de vastgoedsector, gaat het nu nog vooral over milieu en duurzaamheid. Er zijn nog

\footnotetext{
${ }^{1}$ Leefbaarheid: stedelijk groen draagt bij aan gezondheid en welzijn, een aangename woonomgeving voor stedelingen en een positief vestigingsklimaat voor bedrijven.

2 Veerkracht is hoe je met veranderingen kunt omgaan. Deze veranderingen behelzen veel domeinen, zoals klimaat, economie, ecologie, maatschappij, bestuur en technologie (Dijkshoorn et al., 2019).
} 
vele uitdagingen en barrières voordat natuurinclusief bouwen een gangbare praktijk wordt, maar er zijn wel degelijk aanknopingspunten in de wetenschappelijke literatuur.

In dit kader biedt deze rapportage een basis voor een brede enquête onder vastgoedpartijen, voor een verdiepend casusonderzoek naar natuurinclusief bouwen en voor het bieden van handelingsperspectief aan de sector. Met dit vervolgonderzoek beogen we bij te dragen aan een betere vertegenwoordiging van de sociaaleconomische en ecologische waarden van groen in het afwegingskader van de vastgoedsector. 


\section{Summary}

Nature plays an important role in the liveability of towns and cities - urban green spaces help to support health and well-being and offer a pleasant living environment for urbanites and a positive climate for businesses. Green spaces in urban areas are also important for biodiversity and the environment, helping to counter flooding and offering a favourable environment for fauna. Yet in practice, green spaces often succumb to competing claims for space. This can have a significant impact on the living environment of people who live and work in those urban areas.

This project looks at the influence of the real estate industry on urban green spaces. The real estate industry can play a key role in a wider transition to a nature-inclusive living environment that offers social, economic and ecological resilience. In this research, we look explicitly for a pro-active green contribution from the industry to the liveability and resilience of urban areas. We do this by developing a transition approach for nature-inclusive enterprise. This approach looks at the real estate industry more widely, including landowners, investors, architects, property owners and project developers.

In this report, we present a framework for the approach, inspired by three scientific theories: the transition theory, the theory of practice and the theory of planned behaviour. We use the transition theory as a means to describe the process of change to practices in the long term. The theory of practice focuses on the actions that are required in order to construct a residential home from construction materials. The theory of planned behaviour helps us to examine factors that influence practices and how actors are influenced by existing practices. A nature-inclusive industry requires broad change, with that change brought about by a rethink of a wide spectrum of common practices. To set such practices in motion, we are looking for points of departure in the considerations being made by different actors in the real estate industry.

The substantive study of scientific literature relating to nature-inclusive construction has ultimately led to the selection and analysis of 86 scientific publications. Although nature is not a dominant topic in real estate literature - rather the literature tends to reference environmental aspects - there is solid scientific attention for the topic. We distinguish here between eight substantive 'clusters' that are of importance within the scientific literature:

1. The involvement of real estate parties in urban green spaces

2. The role of green spaces in urban areas and the role of real estate practices

3. The use of space in urban areas and the impact of the real estate industry

4. The world of the project developer: practices, considerations and incentives

5. Investment and financing of green spaces in urban areas

6. Planning and governance: management tools for a green urban environment

7. The perspective of the occupant (user)

8. The integration of green and grey: a search for synergies

In this report, we specify the findings from relevant articles for each of the aforementioned clusters.

Ultimately, the role of green spaces on the current or future grey agenda is an important factor for future biodiversity and nature in urban areas. The question is whether or not the colour of the agenda is likely to change. Attention from literature appears to be increasing somewhat, but typically, 'green' in the real estate industry tends to refer primarily to the environment and sustainability. There remain many challenges and barriers to nature-inclusive construction becoming a mainstream practice, but there are solid points of departure in the scientific literature.

In this context, this report offers the basis for conducting a broad survey of real estate parties, for performing an in-depth case analysis of nature-inclusive construction and for providing the industry with an agenda. The aim of this follow-on study is to support better representation of the socioeconomic and ecological values of green areas in the assessment framework of the real estate industry. 


\section{$1 \quad$ Inleiding}

\subsection{Een aanpak voor natuurinclusief ondernemen ontbreekt}

In het kader van belangrijke opgaven op het gebied van milieu, klimaatverandering, gezondheid en welzijn is het van groot belang dat er voldoende groen in steden is (Elmqvist et al., 2015; Haase et al., 2014; Raymond et al., 2017). Een gebrek aan groene ruimte kan milieuproblemen in de toekomst namelijk uitvergroten en de leefbaarheid van steden ernstig onder druk zetten. Stadsgroen heeft een meerwaarde voor de klimaatbestendigheid en leefbaarheid van steden (Raymond et al., 2017) en het vergroten van de biodiversiteit (Fuller et al., 2007). Ook draagt stedelijk groen bij aan een aantrekkelijke leefomgeving voor stedelingen en een goed vestigingsklimaat voor bedrijven (Buijs et al., 2016; Rymarzak en Siemińska, 2012).

Ondanks deze belangrijke functies legt groen het in en om de stad vaak af tegen concurrerende ruimteclaims (Haase et al., 2014). Er zijn omvangrijke claims voor onder andere wonen, werken, voedselproductie, transport, energieproductie, recreatie en water. In Nederland heeft de minister van Binnenlandse Zaken en Koninkrijksrelaties er onlangs nog voor gepleit dat regionale en lokale overheden in de ruimtelijke afweging meer prioriteit moeten geven aan woningbouw (Ollongren, 2018; 2019). Dergelijke ruimteclaims leggen druk op de beschikbare groene ruimte in en rondom de stad en kunnen daarmee een belangrijke invloed hebben op de dagelijkse leefomgeving van de bewoners en de stedelijke biodiversiteit.

Een sector die een grote invloed heeft op ruimtelijke ontwikkelingen in de stad is de vastgoedsector (Roebeling et al., 2017; Sealey et al., 2018). Hieronder verstaan we alle partijen die zich bezighouden met het realiseren en onderhouden van onroerend goed. Dit kunnen partijen met of zonder winstdoelstelling zijn en de betreffende gebouwen kunnen dienen voor wonen, werken of vrijetijdsbesteding. Belangrijke partijen in de vastgoedsector zijn architecten, projectontwikkelaars, stadsplanners, woningcorporaties, bouwbedrijven, grondbezitters en financiële instellingen.

De activiteiten van vastgoedpartijen hebben hun weerslag op de manier waarop steden zich ruimtelijk ontwikkelen. Daarmee heeft de vastgoedsector een significante impact op milieu, economie en samenleving in de stad (Priess et al., 2017). Ondanks het belang van groen in de stad spelen natuur en landschap vaak geen centrale rol in het afwegingskader van partijen uit de vastgoedsector (Dijkshoorn-Dekker et al., 2018), ook niet op braakliggende terreinen. Het belang van natuur en landschap is daarmee niet of slechts beperkt gewaarborgd in veel praktijken. In andere woorden: de vastgoedsector als geheel opereert nog weinig natuurinclusief (Dijkshoorn-Dekker et al., 2018).

Daarom is het doel van dit onderzoek - en onze ambitie - om de vastgoedsector te kunnen ondersteunen bij het maken van afwegingen om natuurinclusief te ondernemen en om zo bestaande vastgoedpraktijken te doorbreken. Het gaat daarbij in dit project niet om specifieke lokale innovaties, maar om een bredere integrale aanpak: een natuurinclusieve verandering op het niveau van de sector, waarbij ook andere relevante stakeholders (zoals gemeenten) worden meegenomen.

Tegen de achtergrond van het voorgaande luidt de vraag die centraal staat in dit vierjarig onderzoek:

Hoe kan de vastgoedsector in beweging gebracht worden om een bijdrage te leveren aan de transitie naar een natuurinclusief stedelijk gebied dat sociaal, economisch en ecologisch veerkrachtig is? 
De deelvragen die de komende jaren worden opgepakt zijn:

1. Wat is de huidige rol van groen in de vastgoedsector?

2. Hoe kan de vastgoedsector geholpen worden om meer natuurinclusief te bouwen, of anders gezegd, wat kan bijdragen aan verandering en beweging in de sector?

3. Welk handelingsperspectief past hierbij?

Met het beantwoorden van de hoofdvraag wordt bijgedragen aan het identificeren van kansen en succes- en faalfactoren voor natuurinclusief ondernemen in de vastgoedsector, en aan inzichten om beweging en samenwerking tot stand te brengen en uiteindelijk belanghebbenden in de stedelijke gebieden een handelingsperspectief te bieden voor natuurinclusief bouwen. Het gaat om het (proactief) handelen ten bate van de biodiversiteit en het integreren van natuur bij (her)ontwikkeling, bouwprojecten en gebiedsontwikkeling in Nederland. Daarmee gaan we op zoek naar de trigger voor een groen verdienmodel met nadruk op biodiversiteit, waarbij de vastgoedsector gaat bewegen en zelf de regie gaat nemen en dus als katalysator/aanjager kan fungeren.

Dit onderzoek draagt bij aan een betere vertegenwoordiging van de sociaaleconomische en ecologische waarden van groen in het afwegingskader van de vastgoedsector. Ook sluit het aan bij EU-doelstellingen voor duurzame ontwikkeling (bv. klimaatverandering, bevolkingsgroei) en de duurzame ontwikkelingsdoelstellingen (Sustainable Development Goals, SDG's). Het gaat dan vooral om SDG's nummer 11: duurzame steden en gemeenschappen; nummer 3: gezondheid en welzijn; en nummer 13: klimaatactie.

De termen groen, natuur, biodiversiteit en natuurinclusief worden in dit rapport naast en door elkaar gebruikt. Onder de term leefbaarheid verstaan we stedelijk groen dat bijdraagt aan gezondheid en welzijn, een aangename woonomgeving voor stedelingen en een positief vestigingsklimaat voor bedrijven. De term veerkracht is gedefinieerd als de wijze waarop je met veranderingen kunt omgaan. Deze veranderingen behelzen veel domeinen, zoals klimaat, economie, ecologie, maatschappij, bestuur en technologie (Dijkshoorn et al., 2019).

\subsection{Gelaagde aanpak}

Het doel van dit vierjarig onderzoek is om een breed beeld te krijgen van de mogelijkheden om de vastgoedsector als geheel meer natuurinclusief te doen opereren alsook om een dieper begrip te ontwikkelen van bepaalde praktijken in deze sector. Uiteindelijk willen we naar het benoemen van een handelingsperspectief voor vastgoedpartijen. Daarom maken we in dit project gebruik van een zogenaamde 'gelaagde aanpak' (layered approach). Dit is een onderzoeksbenadering waarbij diverse methoden in synergie met elkaar worden gebruikt (figuur 1 ).

Door het naast elkaar gebruiken van meerdere onderzoeksbenaderingen worden op verschillende niveaus gegevens verzameld, wat de analyse versterkt doordat er diverse gegevensbronnen en methoden worden gecombineerd (Browne et al., 2014). Het enquête-onderzoek is kwantitatief en schetst een beeld van de uitgangspositie van de vastgoedsector ten aanzien van natuurinclusief bouwen en hun gedrag, inclusief een prioritering van motieven en belemmeringen door vastgoedactoren, terwijl de casestudy's kwalitatief van aard zijn en verdiepend onderzoek bieden om specifieke vastgoedpraktijken te begrijpen. Daarmee is er sprake van triangulatie, wat vaak bijdraagt aan de betrouwbaarheid van de resultaten van het onderzoek (Littig en Leitner, 2017; Schwartz-Shea en Yanow, 2012).

Voor het onderzoek is een conceptueel kader ontwikkeld met een focus op inzicht in aanknopingspunten om het huidige handelen van deze bestaande praktijken in de stedelijke omgevingen te doorbreken. Uiteindelijk is gebleken dat een completer inzicht mogelijk was door de transitietheorie (transition theory) te combineren met de theorie van de praktijk (theory of practice; vaste praktijk van handelen) en met kennis over gedrag, om vervolgens daarop voort te bouwen. Dit kan bijdragen aan het opbouwen van een goede kennisbasis, zowel conceptueel als inhoudelijk. Meer hierover leest $u$ in hoofdstuk 2. 
Parallel aan de ontwikkeling van het conceptuele kader werden de data verzameld. Vanwege de lagenbenadering van deze studie werd gestart met een literatuurstudie en exploratieve diepteinterviews. Deze vormen een verkenning van relevante thema's en afwegingen in de vastgoedsector ten aanzien van het realiseren van een groene omgeving. De exploratieve diepte-interviews vormen, samen met een review van wetenschappelijke literatuur, de basis voor de inhoudelijke thema's die in de andere lagen aan de orde komen: tijdens de enquête en vervolgens ook tijdens de casestudy's.

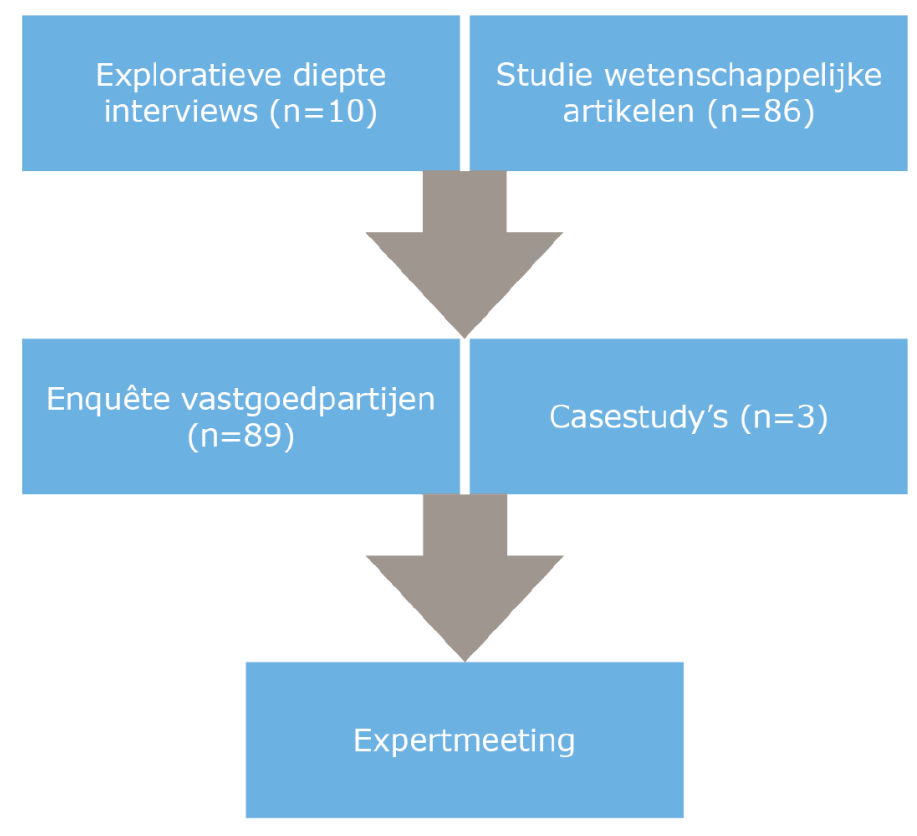

Figuur 1 Gegevensverzameling voor het onderzoek via een lagenbenadering.

De gegevensbenadering bestond, aansluitend op de drie lagen van het onderzoek, uit de volgende onderdelen (zie figuur 1):

\section{Laag 1: Exploratief}

1. Literatuurstudie: Een review van wetenschappelijke literatuur in twee ronden, waarin is gekeken naar de bestaande wetenschappelijke kennis om [1] zicht te krijgen op de huidige rol van groen in de vastgoedsector vanuit een internationaal perspectief en [2] het conceptueel kader te kunnen ontwikkelen. De literatuurstudie dient hiermee zowel de eerste drie deelvragen als de ontwikkeling van het conceptueel kader.

2. Exploratieve diepte-interviews: Kwalitatief onderzoek met tien actoren uit de vastgoedsector om een beeld te krijgen van de manier waarop zij opereren en de wijze waarop groen en biodiversiteit hierbij een rol spelen ten behoeve van deelvragen 1 en 4 en de ontwikkeling van vragenlijsten en prioritering.

\section{Laag 2: Verdiepend}

1. Enquête: Kwantitatief, verkennend onderzoek onder 89 bedrijven uit de vastgoedsector om een breed beeld te krijgen van de huidige situatie met betrekking tot dagelijkse praktijken omtrent groen en biodiversiteit, en tegelijkertijd de mogelijkheden voor verandering in kaart te brengen. De enquête richt zich hiermee op de eerste twee deelvragen en wordt gebruikt om verdere onderwerpen te selecteren voor verdere verdieping middels casestudy's.

2. Casestudy's: Hierin zijn drie natuurinclusieve vastgoedprojecten intensief bestudeerd op de rol van groen en aanknopingspunten voor gedragsverandering vanuit een empirisch perspectief. Per vastgoedproject zijn interviews gehouden met meerder actoren. De casestudy's richten zich hiermee vooral op deelvragen 2, 3 en 4. 


\section{Laag 3: Reflectie}

1. Expertmeeting: Een bijeenkomst waarin diverse partijen uit de vastgoedsector worden uitgenodigd voor het delen van kennis rondom natuurinclusief bouwen. Deze meeting heeft een belangrijke rol in het valideren en bediscussiëren van de resultaten van het onderzoek en levert daarmee input op voor alle vier de deelvragen.

Hieronder volgt een wat uitgebreidere beschrijving van de dataverzameling. Per onderdeel wordt een beschrijving gegeven van de aanpak en de (te verwachten) output. Naast de hieronder beschreven output zal een aantal resultaten van deze vijf onderdelen ook (gedeeltelijk) worden geïntegreerd in een wetenschappelijk artikel.

\section{Literatuurstudie}

Voor het zoeken van relevante literatuur is gebruikgemaakt van de database Scopus, waarin een groot aantal wetenschappelijke artikelen is opgenomen. In deze database is met diverse zoekopdrachten gezocht naar artikelen over de combi 'natuur' en 'vastgoed' (zie bijlage 1). Dit leverde een eerste sample op van ruim zevenduizend artikelen die in verschillende stappen zijn teruggebracht tot een lijst van 86 relevante artikelen, die vervolgens zijn opgenomen in een digitale database. Daarna is een document opgesteld waarin van elk artikel een abstract is opgenomen.

De betreffende artikelen zijn vervolgens bestudeerd door de onderzoekers en bij elke abstract zijn aantekeningen gemaakt om de belangrijkste bevindingen van het artikel in het kader van dit onderzoek te beschrijven. Bij elk artikel is ook globaal door de onderzoekers beschreven op welke (inhoudelijke) thema's het zich richt. Voorbeelden van zulke thema's zijn 'ruimtelijke planning', 'kosten en baten van groen' of 'bewoners van de (groene) stad'. In een volgende stap zijn deze inhoudelijke thema's geclusterd om uiteindelijk tot acht hoofdthema's te komen. Dit is gedaan met behulp van mind-mapping en door groepering op basis van terugkerende terminologie in onze beschrijving. Er is kortom gekeken welke inhoudelijke thema's veelvuldig in de literatuur aan bod kwamen, en op basis hiervan zijn er uiteindelijk acht clusters van artikelen ontstaan (deze zijn niet uitsluitend, of in andere woorden: een artikel kan voor meerdere clusters van belang zijn).

In een volgende stap is bij elk cluster de stand van zaken in de literatuur beschreven. Dit is gedaan in een iteratief proces, waarin diverse onderzoekers met elkaar hebben gespard om de resultaten goed te kunnen duiden. Zie hoofdstuk 3 voor de inventarisatie van de belangrijkste wetenschappelijke literatuur en bijlage 1 voor een uitgebreide beschrijving van de werkwijze in het selecteren van relevante artikelen.

\section{Exploratieve diepte-interviews}

De diepte-interviews zijn uitgevoerd als eerste verkenning van de rol van vastgoedpartijen in relatie tot groen in de stad. Hiertoe zijn in totaal tien interviews afgenomen met diverse actoren uit de vastgoedsector: twee interviews binnen vijf verschillende actorgroepen, te weten projectontwikkelaars, woningcorporaties, vastgoedbeheerders, makelaars en stedelijk ontwerpers.

In deze interviews is uitgebreid besproken welke afwegingen en acties er vanuit deze actorgroepen zijn ten aanzien van natuur en biodiversiteit. Hoe is de vastgoedsector reeds betrokken bij groen in de stad? Hoe kijken ze aan tegen de mogelijke waarde van dit groen? Welke afwegingen maken ze in relatie tot natuur in de stad en welke acties willen ze eventueel ondernemen om natuur en biodiversiteit mee te nemen in hun dagelijkse praktijk? En op welke wijze krijgt dit vorm in de activiteiten die ze ondernemen? De resultaten van deze interviews zijn opgenomen in een rapportage, waarin de exacte vraagstelling verder is toegelicht en waarin de belangrijkste resultaten worden gepresenteerd; zie Dijkshoorn-Dekker et al. (2018). Ook zijn de resultaten gepubliceerd in een artikel (Dijkshoorn-Dekker, 2019).

\section{Enquête}

De vastgoedsector speelt een sleutelrol in de transitie naar een natuurinclusieve omgeving en daarom is het belangrijk om te weten hoe de vastgoedsector over natuurinclusief bouwen denkt. Dit is in kaart gebracht door middel van een enquête. De doelgroep is nogal specifiek en daarom is tijd en aandacht besteed aan het vinden van de doelgroep. Daarbij zijn de vragen per telefoon gesteld. 
Deze (individuele) aanpak heeft geresulteerd in 89 respondenten uit de vastgoedsector, een grote sample binnen de doelgroep voor dit onderzoek. De respondenten zijn geworven op basis van type bedrijf, functie en hun betrokkenheid bij het beslisproces binnen de organisatie of het bedrijf, waarbij ook is gelet op geografische spreiding in Nederland. Onderwerpen die tijdens het interview aan bod kwamen, zijn: huidige situatie, gedrag, motivaties en barrières om natuurinclusief te (gaan) bouwen. Zo werd inzicht verkregen in het huidige gedrag van de respondenten en de manier waarop zij van daaruit geholpen kunnen worden om het gedrag (deels) te veranderen en meer natuurinclusief te gaan bouwen.

De resultaten van de enquête zijn opgenomen in een nog te verschijnen rapportage, waarin de exacte vraagstelling verder is toegelicht en waarin de belangrijkste resultaten worden gepresenteerd (Van Haaster-de Winter et al., 2020).

\section{Casestudy's}

Met het casestudyonderzoek ${ }^{3}$ dat in dit project is uitgevoerd, kijken we specifiek naar een drietal projecten waarin vanuit de vastgoedsector al wordt geïnvesteerd in natuurinclusief bouwen. Deze casussen zijn geselecteerd op basis van een brede inventarisatie van mogelijke cases die via diverse bronnen is uitgevoerd. Dit heeft een groslijst van 41 bouwprojecten opgeleverd, waarvan er na een eerste schifting 17 overbleven. Hierbij was er expliciete aandacht voor natuur en biodiversiteit in combinatie met de ontwikkeling van vastgoed. Uit deze lijst zijn uiteindelijk drie cases geselecteerd op basis van de volgende criteria:

- Het bouwproject is reeds gegund;

- Het gaat om projecten van enige omvang (meer dan een enkele woning of een enkel bedrijfspand);

- De projecten kunnen gezien worden als duidelijk voorbeeld van natuurinclusief ondernemen;

- De projecten verschillen duidelijk van elkaar: commercieel versus niet-commercieel, hoogbouw versus laagbouw, verkoop van vastgoed versus verhuur.

De gegevensverzameling in deze casestudy's heeft plaatsgevonden via een combinatie van documentanalyse/websearch en exploratieve diepte-interviews met meerdere betrokkenen om zo een duidelijk beeld te krijgen van het bouwproject en alles wat daarbij komt kijken, en van de rol van diverse actoren in het proces van idee tot realisatie. Op basis van deze 'goede voorbeelden' (exemplary cases) willen we de lessen leren die deze (op het oog) succesvolle natuurinclusieve bouwprojecten te bieden hebben. Waarom kan het hier wel? Wat loopt er moeizaam en welke obstakels zijn er? Hoe zijn de verschillende vastgoedactoren en andere betrokkenen bij het project gemotiveerd om mee te doen? Wat betekenen dergelijke bouwprojecten nou eigenlijk voor de biodiversiteit? Hierover leest u meer in de brochure van Dijkshoorn-Dekker et al. (2020).

\section{Expertmeeting}

De expertmeeting is een bijeenkomst met diverse partijen uit de vastgoedsector die georganiseerd zal worden nadat de gegevensverzameling en analyse in de andere vier lagen grotendeels is afgerond. Diverse personen die betrokken zijn bij de casestudy's en exploratieve diepte-interviews zullen bij deze meeting worden uitgenodigd om gezamenlijk in discussie te gaan. Doel van deze bijeenkomst is het delen van kennis uit wetenschap en praktijk, evenals het reflecteren op de stand van zaken in dit onderzoeksproject. Deze meeting speelt een belangrijke rol bij het valideren en bediscussiëren van de resultaten van het onderzoek. Daartoe zullen de bevindingen voortkomend uit de eerste vier lagen van dit onderzoek worden gepresenteerd.

Tijdens de expertmeeting gaan we op zoek naar triggers die invloed hebben op het handelen van de vastgoedsector richting natuurinclusief ondernemen. Hiermee heeft deze sessie ook een belangrijke rol in het zoeken naar handelingsperspectief voor natuurinclusief ondernemen in de vastgoedsector. De workshop zal waarschijnlijk om redenen van vertrouwelijkheid niet in een openbaar product resulteren. Wel wordt er een verslag opgesteld voor de deelnemers.

\footnotetext{
3 Het casestudy onderzoek is uitgevoerd samen met Sabine van Rooij en Eveliene Steingröver (Wageningen Environmental Research).
} 


\subsection{Leeswijzer}

In deze achtergrondrapportage gaan we in op de aanpak van het vierjarig onderzoek en presenteren we het conceptueel kader in hoofdstuk 2. In hoofdstuk 3 gaan we in op de uitkomsten van de uitgevoerde literatuurstudie, waarna er in hoofdstuk 4 een reflectie volgt op de stand van zaken in deze context. Deze rapportage vormt de basis voor een enquête onder de vastgoedpartijen (Van Haaster-de Winter et al., 2020) en een nog te verschijnen studie naar praktijkvoorbeelden van natuurinclusief bouwen. 


\section{Conceptueel kader}

Natuurinclusief bouwen is nog geen gemeengoed. We gaan in dit onderzoek uit van het idee dat verandering een wisselwerking tussen gedrag en omgeving is die tot stand komt in de dagelijkse praktijk(en). Daarom gebruiken we in dit onderzoek naast de transitietheorie (Rip en Kemp, 1998) ook de theorie van de praktijk (Schatzki, 2012) en gedrag (Azjen, 1991). Ons idee is dat het proces van verandering naar een natuurinclusieve vastgoedsector verloopt via veranderend gedrag in praktijken die door diverse actoren uitgevoerd worden, zodat uiteindelijk ook het regime verandert. Dit is de kern van het gehanteerde conceptuele kader dat in dit hoofdstuk wordt toegelicht.

\subsection{Bouwstenen voor het conceptueel kader}

\subsubsection{Een natuurinclusieve vastgoedsector vergt brede verandering}

Een wetenschappelijke stroming die zich vooral bezighoudt met het begrijpen en bevorderen van structurele veranderingen richting een duurzamere wereld en samenleving is de transitietheorie. Al sinds eind jaren negentig gebruiken onderzoekers in verschillende disciplines deze theorie om (met elkaar samenhangende) processen van sociale, culturele, economische en technologische verandering te onderzoeken. Daarmee is de transitietheorie een van de meeste gebruikte theorieën om maatschappelijke verandering te duiden (Sovacool en Hess, 2017).

Een transitie wordt gezien als een structurele maatschappelijke verandering. Hierbij veranderen gangbare praktijken en structuren substantieel of worden zij zelfs geheel vervangen door alternatieven (Geels en Schot, 2007). Een dergelijke verandering verloopt niet via een lineair en planmatig proces, maar is een niet geheel voorspelbaar en ingewikkeld proces waarin diverse 'krachten' samenkomen (Frantzeskaki et al., 2016; Grin, 2010; Loorbach, 2010). Een transitie ontstaat dan ook zelden vanuit één actor. Bijna altijd is het een samenspel van diverse sectoren, waarbij overheden, de markt, maatschappelijke organisaties en burgers een rol spelen.

Centraal in het gebruik van de transitietheorie staat het multi-levelperspectief (MLP, figuur 2). Dit raamwerk wordt gebruikt om te begrijpen hoe transities tot stand kunnen komen en hoe hierop kan worden ingespeeld om verandering op gang te brengen. Daarbij wordt naar transities gekeken op drie verschillende (schaal)niveaus: 'landschap', 'regime' en 'niche' (Poppe et al., 2009; Rip en Kemp, 1998; Van Dam et al., 2016). Hoe hoger het schaalniveau, hoe geaggregeerder de componenten en hoe trager de dynamiek. Het sociaalecologische landschap is vooral de context waarbinnen verandering plaats moet vinden. Dit landschap omvat langzaam veranderende, overkoepelende structuren en diepgewortelde levensprincipes die het speelveld vormen waarbinnen een mogelijke transitie plaatsvindt. Het gaat dan om bijvoorbeeld demografie, macro-economie, materiële infrastructuur, klimaat, biodiversiteit, het fysieke landschap en diepgewortelde tradities. Het regime omvat bestaande, gangbare praktijken, algemeen geaccepteerde regels, vigerend beleid en bestuurlijke structuren. Bij een transitie gaat het meestal om een verandering op regimeniveau, waarbij in ons geval de gangbare praktijk meer natuurinclusief wordt. Bij niches gaat het om lokale projecten en innovatieve of afwijkende praktijken die nog niet gangbaar zijn, maar waar vanuit nieuwe regimes kunnen ontstaan. Op dit niveau is er het meeste dynamiek, terwijl het landschap het meest stabiel is. 


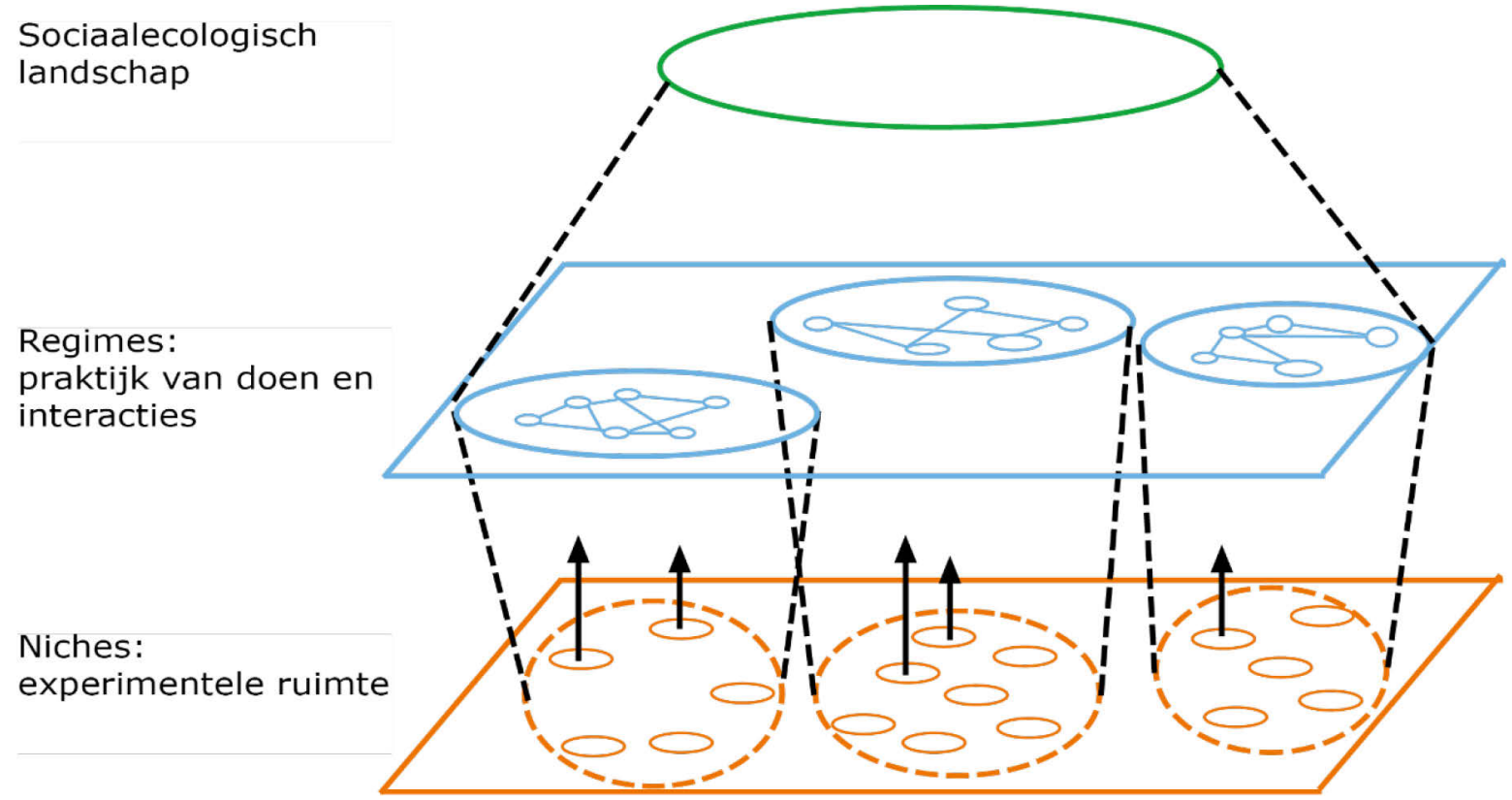

Figuur 2 Het multi-levelperspectief (Geels, 2002, bewerking Wageningen Economic Research)

Er ontstaat steeds meer het bewustzijn dat transities niet zozeer planmatig ontstaan door sturing van bovenaf, maar ook voor een groot deel het gevolg zijn van veranderingen in de dagelijkse praktijk en dus ontstaat van onderop (Aalbers en Sehested, 2018; Hargreaves et al., 2013; Rauschmayer et al., 2015; Shove en Walker, 2010). Transities vinden dus plaats in de praktijk (en niet achter de tekentafel).

\subsubsection{Het vernieuwen van praktijken}

Een verandering op regimeniveau vergt een verandering van een breed scala aan praktijken (Rauschmayer et al., 2015). Een theorie die zich specifiek richt op het begrijpen van zulke (veranderende) praktijken is de theorie van de praktijk (theory of practice). In tegenstelling tot theorieën die zich vooral op het handelen van de individuele actor of juist op de sturende rol van instituties en structuren richten, ligt de focus in deze theorie op de dagelijkse praktijk van het menselijk handelen. Zo'n praktijk bestaat uit een aantal elementen (tabel 1): met elkaar samenhangende 'handelingen', 'betekenissen' en 'materialiteit' (Arts et al., 2012; Røpke, 2009; Shove et al., 2012). De theorie van de praktijk gaat niet uit van uniformiteit, maar van een breed scala aan praktijken die door diverse practitioners worden uitgevoerd (Behagel, 2012; Røpke, 2009). Voorbeelden van zulke praktijken zijn tuinieren of het doen van boodschappen, maar ook investeren en het bouwen van huizen. Bij het bouwen van huizen (handeling) spelen bouwmaterialen bijvoorbeeld een belangrijke materiële rol, maar ook ideeën over comfortabel wonen, functionaliteit, winstgevendheid en duurzaamheid maken deel uit van deze praktijk (betekenis).

\section{Tabel 1 Elementen van een praktijk}

\begin{tabular}{ll}
\hline Handelingen & Activiteiten die mensen (fysiek) ondernemen binnen een praktijk \\
\hline Betekenissen & Symbolen, taaluitingen en verhalen die deel uitmaken van een praktijk \\
\hline Materialiteit & Objecten die gebruikt worden of een plaats hebben binnen een praktijk \\
\hline
\end{tabular}

In de wetenschap worden de theorie van de praktijk en de transitietheorie steeds vaker als complementair gezien en samen gebruikt (Hargreaves et al., 2013; Rauschmayer et al., 2015; Van Dam et al., 2016). Wij volgen dit uitgangspunt omdat beide elkaar aanvullen bij het begrijpen en bevorderen van verandering in een context waarin praktijken niet eenduidig en makkelijk stuurbaar zijn (Rauschmayer et al., 2015; Watson, 2012). 
In de theorie van de praktijk wordt benadrukt dat een praktijk niet zomaar ontstaat en bestaat: er moet een eindpunt of doel zijn waarom mensen een praktijk beoefenen. Dit wordt ook wel een telos genoemd (Schatzki, 2010): een 'toekomstige dimensie' waardoor mensen zich in een praktijk mengen (Shove en Spurling, 2013). Zoals Rauschmayer et al. (2015) benoemen, zullen transities niet zomaar ontstaan, omdat praktijken pas veranderen wanneer daar een reden voor is; anders hebben praktijken de neiging om volgens vaste patronen te blijven verlopen (Reckwitz, 2002).

Ter illustratie het voorbeeld van paardrijden. Deze praktijk bestaat nog steeds, maar was vroeger vooral belangrijk voor transport en tegenwoordig vooral voor recreatie en sport. Praktijken kunnen veranderen omdat nieuwe elementen beter aansluiten bij de doelstellingen van de actoren die deze praktijken uitoefenen. Een voorbeeld uit de vastgoedsector is dat prefab-bouwen tegenwoordig meer wordt toegepast omdat door een nieuwe technologische ontwikkeling een bepaalde bouwhandeling (kosten)efficiënter kan worden uitgevoerd.

\subsubsection{Veranderend gedrag in diverse praktijken}

De theorie van de praktijk is echter geen "allesomvattende theorie: bijvoorbeeld de psychologische factoren die de adoptie van nieuwe technologieën bepalen en daarmee het doorbreken van praktijken, de motivaties voor uitoefenaars van een praktijk om een groep te verlaten of zich juist hierbij aan te sluiten, en hoe te komen tot het ontwikkelen van bepaalde praktijken zijn geen centrale vragen in de theorie van de praktijk" (Spangenberg en Lorek, 2019). Dat heeft onder andere te maken met de onderzoekseenheid: "de praktijk zelf, in plaats van de individuen die deze praktijk uitvoeren of de sociale structuren die hen omringen, wordt daarmee de kerneenheid van analyse" (Hargreaves, 2011, vertaald uit Engels). Menselijk gedrag bepaalt voor een belangrijk deel de wijze waarop praktijken vorm krijgen (Schatzki, 2010). Daarom maken we ook gebruik van aanvullende inzichten in het dagelijkse gedrag van de actor. Ajzen (1991) geeft aanknopingspunten voor gedragsverandering. Hij laat zien dat gedrag voorafgegaan wordt door een intentie, die gevormd wordt door een combinatie van drie factoren, namelijk: attitudes, subjectieve normen en waargenomen gedragscontrole (zwart in figuur 3). In brede zin kan worden gezegd dat de intentie om bepaald gedrag te vertonen sterker is wanneer deze factoren positief zijn.

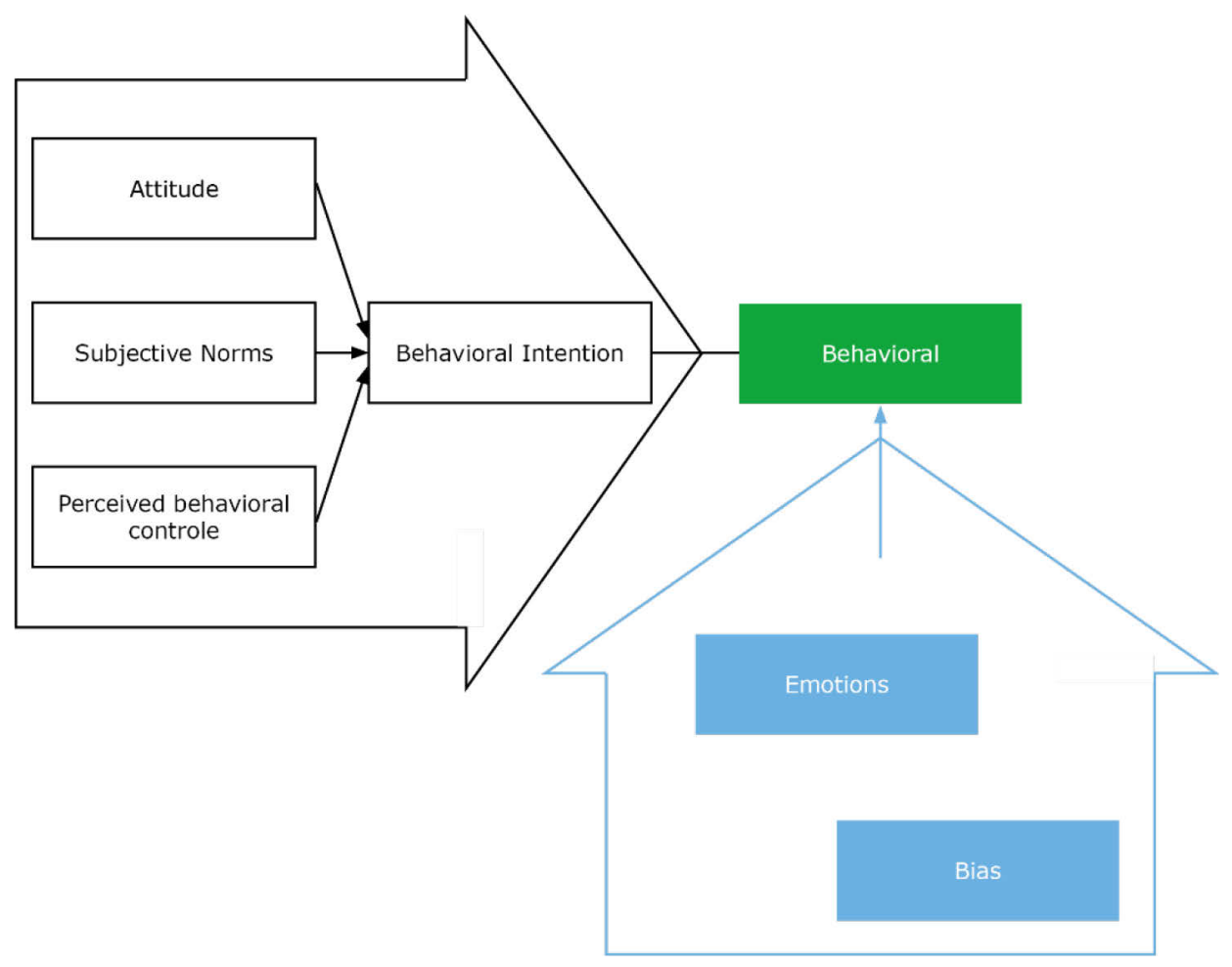

Figuur 3 Het intentionele gedrag van de actor (zwarte pijl van links naar rechts/groene rechthoek) wordt ook beïnvloed door onbewuste processen (blauwe pijl, van onder naar boven) (Ajzen, 1991, bewerking Wageningen Economic Research) 
Het beoogde gedrag wordt evenwel niet altijd uitgeoefend. In dit kader is het belangrijk te noemen dat mensen niet alleen rationele keuzes maken op basis van een intentie, maar dat onbewuste processen ook een relevante rol spelen. Onze rationaliteit is namelijk beperkt doordat er (biologisch gezien) grenzen aan het denkvermogen zitten (Simon, 1982). Dit heeft als gevolg dat het gewoonweg niet mogelijk is om alle informatie om ons heen te verwerken. Een deel wordt dan ook onbewust verwerkt en beïnvloedt op die manier gedrag (blauw in figuur 3). Kahneman (2011) heeft het in dit kader over twee verschillende manieren van denken, die systeem 1 en 2 worden genoemd, respectievelijk: snel en intuïtief (de plek voor gewoontes) versus langzaam en weloverwogen (de plek voor ratio). Gewoontes zijn een bekend voorbeeld van beslissingen die snel en effectief worden genomen, en juist dit gewoontegedrag is een belangrijk onderdeel van veel praktijken (Shove et al., 2012).

Gewoontegedrag vindt onbewust plaats (Wood \& Neal, 2009) en wordt getriggerd door de omgeving (Neal et al., 2009). De theorie van de praktijk benadrukt dat veel gedrag na verloop van tijd in vaste patronen gaat verlopen en onderdeel wordt van een (bestaande) praktijk (Shove et al., 2012). Gewoontes worden vaak niet voorspeld door intentie (De Bruijn et al., 2008). Juist daarom blijven dingen zoals ze zijn: bestaande praktijken blijven voortbestaan omdat gedragspatronen in deze praktijken niet veranderen.

\subsection{Conceptueel kader natuurinclusief ondernemen}

Voorgaande paragrafen leveren de bouwstenen voor het raamwerk zoals dat binnen dit onderzoek gehanteerd wordt. Om inzicht te krijgen in mogelijke handelingsperspectieven voor bedrijven in de vastgoedsector om meer natuurinclusieve praktijken te ontwikkelen en te realiseren, wordt geput uit deze theoretische stromingen. De transitietheorie legt de focus op grote, structurele veranderingen richting een natuurinclusieve leefomgeving; de theorie van de praktijk kijkt naar de dagelijkse praktijken in de vastgoedsector; en de theorie van gepland gedrag (theory of planned behaviour) is in ons onderzoek toegespitst op het handelen van individuele actoren. We gebruiken de inzichten uit de drie theorieën om veranderingsprocessen op verschillende niveaus te begrijpen.

Om het doorlopende proces van verandering helder te maken, hebben we bovenstaande inzichten vertaald in een figuur, waarbij we praktijk en keuzegedrag integreren in een transitiecurve zoals die in de transitietheorie vaker wordt gebruikt (figuur 4). Deze curve geeft het (ideaaltypische)

veranderingsproces in de loop van de tijd weer. Een transitie verloopt niet lineair en geleidelijk, maar doorloopt meerdere fasen met verschillende tempo's om uiteindelijk in een nieuw evenwicht te komen. Hierbij staat RO (regime 0) voor de huidige situatie en R1 voor de natuurinclusieve eindsituatie waar we naartoe willen.

- Elke cirkel op de curve stelt een momentopname voor in het transitieproces, met praktijken en bijbehorend gedrag van actoren die passend zijn voor dat moment in de tijd.

- De rode pijlen geven aan dat er door de tijd heen druk uitgeoefend wordt op bestaande praktijken, waardoor deze in beweging komen.

- Wanneer de beweging genoeg massa krijgt, vindt verandering van de ene cirkel naar de andere cirkel plaats. Dit wordt weergegeven middels de zwarte pijlen.

Hoewel de afbeelding slechts één veranderende praktijk laat zien, is het belangrijk om te beseffen dat het werkelijke speelveld bestaat uit een breed scala aan praktijken die meer of minder natuurinclusief zijn en dat werkelijke transities vaak minder gestructureerd verlopen dan deze ideaaltypische figuur doet vermoeden. 


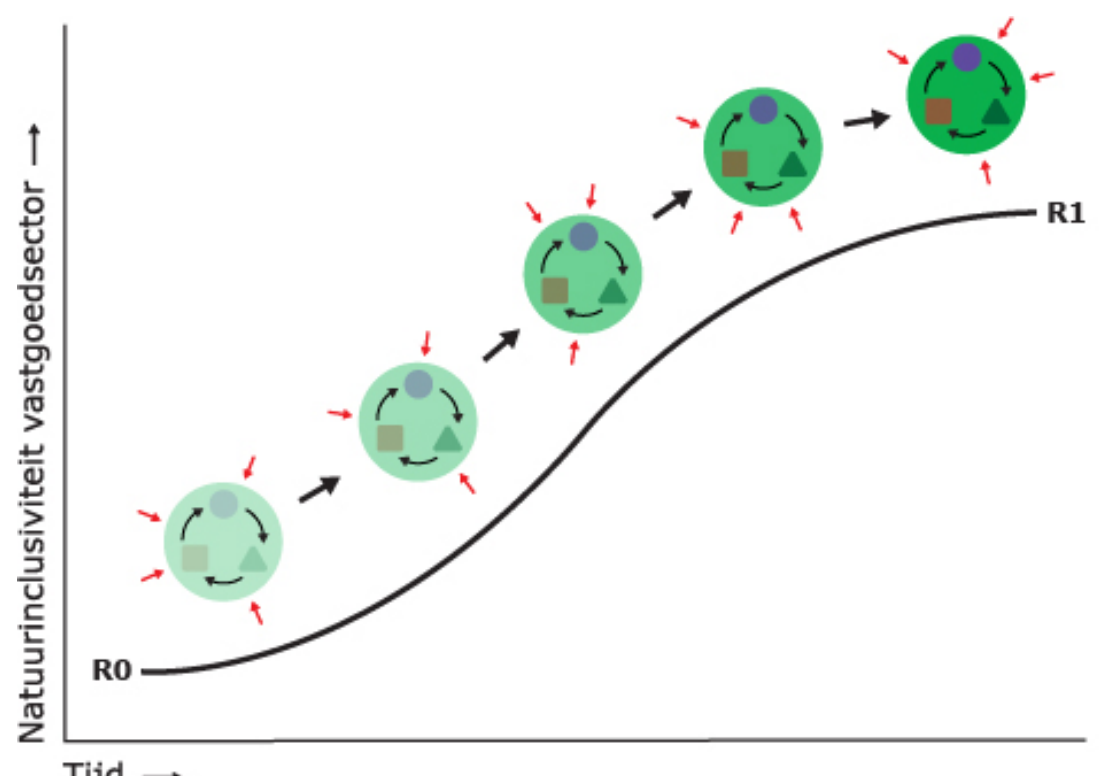

Tijd $\rightarrow$

Figuur 4 Schematische weergave van het conceptuele kader voor het stimuleren van natuurinclusief ondernemen en het doorbreken van bestaande vastgoedpraktijken en gedrag. De gebruikte kleuren worden donkerder naarmate de praktijk (bol) natuurinclusiever wordt. De praktijk vertegenwoordigt handelingen (paars rondje), betekenissen (groen driehoekje), materialiteit (bruin vierkantje) en gedrag (groene achtergrondkleur).

De verandering die wordt weergegeven, analyseren we middels vijf kritische en met elkaar verbonden aspecten, die onderscheiden worden in Dijkshoorn-Dekker et al. (2017). Dit zijn: 'visie', 'stakeholders', 'middelen', 'concrete activiteiten' en 'leren'. Hieronder vertalen we deze dimensies naar de vastgoedsector:

Visie en agenda: Praktijken werken toe naar een doel, een telos (Schatzki, 2012). In de vastgoedsector is momenteel geen sprake van een gedeelde, natuurinclusieve visie (DijkshoornDekker et al., 2018). Daarmee is een brede natuurinclusieve verandering in de praktijken in deze sector ook niet voor de hand liggend. Het proces van verandering in deze sector vraagt om een gedeelde natuurinclusieve visie, dan wel om natuurinclusieve oplossingen die passen binnen het doel van bestaande praktijken en daarmee aansluiten bij bestaande visies.

Betrokkenheid en rol van actoren: $\mathrm{Er}$ is een sterke link tussen de betekenis binnen een praktijk en de actie die mensen ondernemen (Arts et al., 2013). Toch laten inzichten uit zowel de theorie van de praktijk als de gedragseconomie zien dat een visie of idee alleen niet altijd genoeg is om daadwerkelijk aan de slag te gaan. Zoals we al eerder concludeerden, is er een reden tot verandering in de praktijk nodig, een bepaalde urgentie die vastgoedactoren in beweging zet en die zorgt dat zij daadwerkelijk betrokken zijn bij de gewenste veranderingen.

Middelen: Ook wanneer de urgentie wel wordt gevoeld en actoren zich actief inzetten, wil dit nog niet zeggen dat er ook (gewenste) resultaten worden behaald (Aalbers et al., 2018). Een belangrijke succesfactor is de beschikbaarheid van voldoende middelen. Materialiteit speelt een centrale rol in de theorie van de praktijk, wat zich vertaalt in de beschikbaarheid van de juiste apparatuur en het geld om te kunnen investeren. Ook vaardigheden, competenties en kennis zijn belangrijk om effectief en succesvol te kunnen handelen (Shove et al., 2012), bijvoorbeeld om groen te kunnen ontwerpen en groene oplossingen te kunnen opnemen in bouwplannen.

Concrete activiteiten: Voor een transitie is het belangrijk dat er verandering voorbij de individuele praktijk is (Rauschmayer et al., 2015). Het effect is immers veel groter wanneer er een breed scala aan natuurinclusieve activiteiten wordt ontplooid in diverse praktijken. Het gaat dan ook juist om het opschalen en/of verbreden van natuurinclusieve praktijken in de brede vastgoedsector. 
Iteratief leerproces: Een transitie is geen georganiseerd en gestructureerd proces van A naar B.

Transities zijn complex en moeilijk stuurbaar en krijgen stapsgewijs vorm (Frantzeskaki et al., 2016; Grin, 2010). Het gaat dus veel meer om een proces van kleine stapjes zetten, leren en weer bijsturen. Het leren, reflecteren, monitoren en bespreken van verandering met de betrokken partijen speelt een belangrijke rol om dit proces op gang te houden en om in beweging te blijven. 


\section{Rol van de vastgoedsector in het internationale perspectief}

Als deel van dit project is in samenhang met het conceptuele kader in de internationale wetenschappelijke vastgoedliteratuur gezocht naar verdere aanknopingspunten en inzichten rondom de rol van groen in de vastgoedsector. Er is bewust gekozen voor de internationale wetenschappelijke literatuur, omdat het nationale speelveld al nadrukkelijk aan de orde is gekomen in Dijkshoorn et al. (2018). Uit Dijkshoorn et al (2018) volgde dat voor de meeste bedrijven in de vastgoedsector (bijdragen aan meer) groen in de stad nog geen onderdeel uitmaakt van de visie en/of agenda.

Dit hoofdstuk presenteert de belangrijkste bevindingen van deze zoektocht en is ingedeeld naar de volgende acht onderwerpen:

1. Maatschappelijke betrokkenheid bij groen in de stad

2. Functie van groen in de stad

3. Landgebruik en impact van de vastgoedsector

4. De wereld van de projectontwikkelaar: praktijken, afwegingen en incentives

5. Investering en financiering van groen

6. Planning en governance

7. Het perspectief van de consument (bewoner/gebruiker)

8. De integratie van groen en grijs: een zoektocht naar synergiën

\subsection{Maatschappelijke betrokkenheid bij groen in de stad}

De laatste jaren wordt de samenleving door (gemeentelijke) overheden steeds meer betrokken bij natuur in het stedelijk gebied. Overheden streven ernaar dat ondernemers en burgers meer 'natuurinclusieve' praktijken gaan ontplooien (Dijkshoorn et al., 2014). Hiernaast organiseren steeds meer maatschappelijke partijen zich ook om op eigen initiatief met groen in de stad aan de slag te gaan (Mattijssen et al., 2019). Daarmee is er dus zowel van bovenaf als van onderop een wens tot vergroening van de stad.

De praktijk is echter weerbarstig. In veel steden staan de kwaliteit en kwantiteit van het aanwezige groen en de daarmee samenhangende stedelijke biodiversiteit onder druk door doorlopende stadsuitbreidingen en afnemende budgetten voor groenonderhoud (Burton et al., 2014; Kabisch, 2015). Als gevolg hiervan wordt de inzet van diverse maatschappelijke actoren ook steeds belangrijker voor de natuur in en om de stad. Met hun dagelijkse doen en laten hebben zij immers een belangrijke invloed op de natuur in de stad en kunnen ze positief bijdragen aan de stedelijke biodiversiteit (Van der Jagt et al., 2016).

De eigenaar van stedelijk groen in de publieke ruimte is vaak een overheid. Bij publiek groen gaat het meestal over parken, perken, grasvelden, bloembakken en bomen. Veel stedelijk groen valt echter ook onder privaat eigenaarschap: grond in eigendom van een bedrijf dat daar is gevestigd, een vastgoedbedrijf dat eigenaar is van de locatie, particuliere huiseigenaren of woningbouwverenigingen. Ook privaat groen in de tuinen van mensen en op bedrijventerreinen levert belangrijke waarden en draagt bij aan de leefbaarheid en het ecosysteem van de stad (Cameron et al., 2012; Coolen en Meesters, 2012). Privaat bedrijfsgroen kan bestaan uit bloembakken, perken, bomen en groen op het dak, aan de gevel of op de private grond in nabijheid van een bedrijfspand. Overheden hebben in veel gevallen slechts beperkt zeggenschap over het beleid en beheer van deze groene ruimte.

Als we kijken naar de rol die maatschappelijk actoren spelen bij het groen, dan gaat het niet alleen om de rol van burgers en lokale ngo's maar ook om het bedrijfsleven. Vanuit het ondernemerswezen zijn diverse partijen met eigen doelstellingen en middelen actief in het stedelijk groen (Van der Jagt et al., 2016), en er bevindt zich ook het nodige groen op bedrijventerreinen. Groene activiteiten vanuit het bedrijfsleven kunnen een uiting zijn van sociaal ondernemerschap, maar er zit vaak ook een zakelijke 
dimensie aan. Voor veel bedrijven is het echter nog een uitdaging om op zoek te gaan naar nieuwe verdienmodellen waarin meerwaarde wordt gerealiseerd middels de aanleg en het onderhoud van groen in de stad (Toxopeus en Polzin, 2017).

\section{De rol van de vastgoedsector}

Een belangrijke speler in de bovenstaande stedelijke ontwikkelingen is de vastgoedsector. Diverse onderzoeken laten zien dat partijen in het vastgoed een grote invloed hebben op ruimtelijke ontwikkelingen in de stad (Roebeling et al., 2017; Sealey et al., 2018). Activiteiten van architecten, projectontwikkelaars, stadsplanners, woningcorporaties, bouwbedrijven en ook financiële instellingen hebben alle hun weerslag op de manier waarop steden zich ruimtelijk ontwikkelen. Daarmee heeft de vastgoedsector een significante impact op milieu, economie en samenleving in de stad (Priess et al., 2017). Ondanks het belang van groen in de stad spelen natuur en landschap vaak geen centrale rol in het afwegingskader van partijen uit deze sector (Dijkshoorn-Dekker et al., 2018). Sterker nog, diverse onderzoeken stellen dat de huidige vastgoedindustrie en de wijze waarop we momenteel wonen in steden niet duurzaam zijn (Battisti et al., 2017; Vanags en Butane, 2013). Het belang van natuur en landschap is daarmee niet of slechts beperkt gewaarborgd in veel praktijken van de vastgoedsector.

De zorg voor een kwalitatief hoogwaardige leefomgeving wordt tegenwoordig echter ook als een maatschappelijke verantwoordelijkheid voor projectontwikkelaars gezien (Dobson en Jorgensen, 2015). Daarnaast is er ook vraag naar groen vanuit de consument. Veel mensen wonen bij voorkeur in een groene en gezonde omgeving (Maruani en Amit-Cohen, 2013). De aanwezigheid van groen verhoogt ook de waarde van nabijgelegen huizen en draagt bij aan een aantrekkelijk vestigingsklimaat voor diverse ondernemers (Cinderby en Bagwell, 2018; Wilkinson et al., 2012). In het kader van belangrijke opgaven op het gebied van milieu, klimaatverandering, gezondheid en welzijn is het dan ook van groot belang dat er voldoende groen in steden is (Elmqvist et al., 2015; Haase et al., 2014; Raymond et al., 2017). Een gebrek aan groene ruimte kan milieuproblemen in de toekomst namelijk uitvergroten en de leefbaarheid van steden ernstig onder druk zetten. Indien er in de vastgoedsector geen omslag plaatsvindt, kan dit op termijn een grote impact hebben op de beschikbaarheid en kwaliteit van stedelijk groen, wat zijn weerslag kan hebben op bestaande verdienmodellen in deze sector (Vanags en Butane, 2013).

\subsection{Functie van groen in de stad}

\section{Positieve effecten en neveneffecten}

Er is een behoorlijk aantal studies dat de baten van groen benoemt (zoals Mittal en Byahut, 2017; Moseley et al., 2013; Coolen en Meesters, 2013; Green et al., 2013; Ignatieva en Ahrné, 2013; Mei et al., 2018; Elmqvist et al., 2018; Cinderby en Bagwell, 2018). Deze baten worden op kwalitatieve en kwantitatieve wijze in kaart gebracht.

Natuur heeft een meerwaarde voor klimaatbestendige en leefbare steden. De aanwezigheid van natuur in de stad heeft een positieve invloed op de gezondheid en het welzijn van mensen (Raymond et al., 2017) en de biodiversiteit (Fuller et al., 2007). Ook draagt stadsgroen bij aan een aantrekkelijke leefomgeving voor stedelingen en een goed vestigingsklimaat voor bedrijven (Buijs et al., 2016; Rymarzak en Siemińska, 2012). Bovendien speelt stedelijk groen een belangrijke rol in het kader van klimaatverandering en milieuproblematiek. Hieronder vallen het verminderen van wateroverlast en hittestress en het beperken van geluidsoverlast en luchtvervuiling (Haase et al., 2014).

$\mathrm{Er}$ is daarmee in de door ons verzamelde literatuur een breed gedeelde opvatting dat groen in de stad bijdraagt aan ecologische, milieutechnische, economische, sociale en culturele waarden. Negatieve effecten van groen worden slechts sporadisch genoemd. De aanwezigheid van wilde dieren in de groene ruimte kan bijvoorbeeld als negatief worden ervaren (Broitman et al., 2016). En in de eigen achtertuin kunnen negatieve effecten voor het milieu ontstaan door bijvoorbeeld het gebruik van bestrijdingsmiddelen en de introductie van mogelijk invasieve exoten (Cameron et al. 2012). 
De breed onderschreven positieve effecten (ecologische en milieutechnische effecten van groen) en neveneffecten (sociaaleconomische effecten van groen) worden in veel literatuur gebruikt ter onderbouwing van groene visies op de stad. In veel van de bovenstaande literatuur is de insteek om diverse partijen met een rol in de vastgoedsector (overheden, projectontwikkelaars, bewoners, bedrijven) aan te zetten om iets met groen te doen.

\section{Publiek versus privaat groen}

Niet alleen publiek groen levert belangrijke positieve effecten en neveneffecten op. Ook privaat groen in de tuinen van mensen en op bedrijventerreinen levert belangrijke waarden aan de stad (Coolen en Meesters, 2012; Cameron et al., 2012). Publiek en privaat groen hebben verschillende functies, maar zijn beide belangrijk voor mens en milieu. Publiek groen draagt in sociale zin bij aan leefbaarheid en natuurbeleving; privaat groen in de tuin is meer een extensie van het huis en een persoonlijke plek voor rust en ontspanning (Coolen en Meesters, 2012; Cameron et al. 2012). Beide kunnen ecologisch waardevol zijn en zijn in de praktijk vaak met elkaar verbonden.

Een interessante maar in de literatuur nog kleine discussie gaat over de rol van en keuze voor publiek versus privaat groen bij stadsontwikkeling. In Nederland is er bij stadsontwikkeling vaak een keuze tussen vooral publieke groene ruimte (parken, plantsoenen) of private ruimte (tuinen). Door de focus op compacte steden ontstaat meer nadruk op publiek groen en is er minder ontwikkeling van privaat groen (Coolen en Meesters, 2012). Over de verschillen in onderhoudskosten die met deze keuze samenhangt, is nog weinig geschreven.

\subsection{Landgebruik en impact van de vastgoedsector}

\section{De impact van de vastgoedsector op landgebruik, natuur en milieu}

In meerdere onderzoeken wordt benadrukt dat diverse partijen uit de vastgoedsector (financiers, projectontwikkelaars) een grote invloed hebben op ruimtelijke ontwikkelingen in de stad, zoals urbanisatie en veranderingen in landgebruik (o.a. Sealey et al., 2018; Roebeling et al., 2017). De invloed van de vastgoedindustrie op het milieu wordt in de literatuur gezien als groot (o.a. Priess et al., 2017). Vanags en Butane (2013) leggen zelfs een expliciete link tussen de huidige ecologische crisis en de praktijken vanuit de vastgoedsector.

Op diverse wijzen wordt door vele onderzoekers gesteld dat de huidige vastgoedindustrie en de manier waarop we nu wonen niet duurzaam zijn op het gebied van natuur en milieu (Sealey et al., 2018; Lindholm, 2017; Grafakos et al., 2016). Belangrijke negatieve impacts van de vastgoedsector die worden benoemd, zijn onder andere energie-exploitatie, milieuvervuiling, aantasting van de biodiversiteit en schaarste aan grondstoffen (Vanags en Butane, 2013). Daarnaast zijn er ook negatieve sociaal-maatschappelijke impacts (zie paragraaf 3.8). Phenton (2013) betoogt hoe ook de ontwikkeling van (auto-)infrastructuur niet alleen ten koste van milieu en sociale waarden gaat, maar tevens ten koste gaat van andere economische belangen. In vrijwel alle artikelen die dergelijke negatieve impacts van de vastgoedsector bespreken, wordt er een noodzaak tot duurzaamheid en/of vergroening bepleit.

\section{Een transitie naar een andere impact en ander landgebruik}

De noodzaak tot (ecologische) verandering in de vastgoedsector wordt in diverse papers benoemd. In veel van deze papers wordt, vaak gebaseerd op bepaalde normatieve principes, ook betoogd wat er anders moet en waarom. Zo beargumenteren Battisti et al. (2017) dat de vastgoedsector om natuuren milieuredenen (landgebruik, energie, natuur) moet veranderen om duurzaam te blijven en aan te sluiten bij maatschappelijke opgaven. Fu et al. (2017) benoemen dat een stedelijke 'groene' transitie, waarbij ook partijen uit de economische sectoren betrokken moeten zijn, noodzakelijk is om een duurzame toekomst voor het fragiele ecologische milieu in de stad te kunnen creëren. Ook de (gewenste) rol van stadsplanners in deze verandering wordt in een aantal papers benadrukt (Lindholm, 2017; Price et al., 2015).

De noodzaak tot ecologische verandering wordt in een aantal studies expliciet gekoppeld aan sociale problematiek (Battisti et al., 2017; Endsley et al., 2018; Haase et al., 2017). Ook het welzijn van de 
bevolking is hier een belangrijk punt van aandacht (Battisti et al., 2017). Termen als stedelijke herontwikkeling, milieurechtvaardigheid en gentrificatie geven aan dat men ook probeert sociale en economische structuren van wijken te veranderen, waarbij groen een duidelijke rol kan spelen (Haase et al. 2017).

Hoewel in de literatuur wordt gesproken over (de noodzaak tot) verandering, is het opvallend dat in de door ons geïnventariseerde literatuur eigenlijk niet of nauwelijks gebruik wordt gemaakt van de transitietheorie. De paper van Fu et al. (2017) is het enige artikel dat in de abstract de notie van een transitie heeft opgenomen. Het transitieraamwerk in zijn vele vormen heeft daarbij nog allerminst een centrale rol in de vraagstukken waarop dit project zich richt en wordt nog weinig gebruikt in relatie tot bijvoorbeeld vraagstukken op het gebied van energie.

\subsection{De wereld van de projectontwikkelaar: bestaande praktijken, afwegingen en incentives}

\section{De lage prioriteit van groen}

Een aantal studies naar de activiteiten en drijfveren van projectontwikkelaars en stadsplanners suggereert dat groen in de dagelijkse praktijk nog vaak fungeert als een soort sluitpost, die pas wordt ingevuld als de belangrijke (economische) randvoorwaarden zijn vastgesteld (Moseley et al., 2013; Denjean et al., 2017; Vanags en Butane, 2017). In stadsplanning is groen vaak ondergeschikt aan verkeer, wonen en zakelijk (Moseley et al. 2013; Phenton, 2013), wat ook weer doorwerkt in de afwegingskaders van ondernemers bij het ontwikkelen van vastgoed of infrastructuur. Ook welzijn en gezondheid worden door projectontwikkelaars vaak beperkt meegenomen in hun dagelijkse praktijken omdat zij daar maar weinig financieel-economische incentives voor zien (Trowbridge, 2013).

\section{De maatschappelijke druk op projectontwikkelaars}

Ondanks bovenstaande observaties wordt vanuit zowel burgers als overheden steeds vaker van projectontwikkelaars verwacht dat zij ook hun sociaalmaatschappelijke verantwoordelijkheden nemen (Battisti et al., 2017; Dobson, 2015; Elmqvist et al., 2018; Manzo, 2015). Hieronder valt ook het realiseren en/of beschermen van groen, wat in huidige westerse samenlevingen steeds meer als een gedeelde verantwoordelijkheid wordt gezien en niet meer alleen als een taak voor overheden (Dobson en Jorgensen, 2015).

Het onderzoek dat is verricht vanuit het perspectief van bewoners laat daarnaast in veel studies zien dat zij groen in de woonomgeving (en in de achtertuin) belangrijk vinden/prioriteren (Coolen en Meesters, 2012; Simmons en Krokfors, 2015). Voor veel bewoners op de woningmarkt speelt groen dus wel een belangrijke rol in het afwegingskader, bijvoorbeeld door een prioritering van huizen met tuin (Coolen en Meesters, 2012). Sommige artikelen schrijven dat vastgoedontwikkelaars uit commerciële overwegingen moeten proberen aan te sluiten bij deze vraag vanuit de markt (Ponizi et al., 2017; Coolen en Meesters, 2012; Hussain et al., 2014) De vraag naar groen is dus niet alleen een maatschappelijke opgave en verantwoordelijkheid die ligt bij projectontwikkelaars, maar ook een incentive die volgt vanuit deze marktbehoefte.

\section{Groen als investering en marketing}

Ondanks een aantal artikelen over de lage prioritering van groen investeren projectontwikkelaars wel degelijk in groen. Wel zijn dergelijke investeringen in veel gevallen ondergeschikt aan of complementair met strategieën om via vastgoed geld te verdienen. Groen wordt dus vooral ingezet vanuit of ter aanvulling op bestaande verdienmodellen. Toch zijn er ook papers waarin wordt benoemd dat ontwikkelaars steeds meer gericht in groen investeren, met als doel om de waarde van huizen te verhogen (Yuling, 2017) of de winst te maximaliseren. Butane en Vanags (2013) betogen dat vastgoedpartijen meer sociaal en ecologisch duurzaam moeten opereren omdat dit van belang is om ook in de toekomst competitief te blijven.

Cinderby en Bagwell (2018) laten zien dat vergroening van een commercieel district in Londen resulteert in meer omzet voor bepaalde typen ondernemers: vooral in de retail en de vrijetijdssectoren 
is het aantal bezoekers en de totale verkoop toegenomen. Ze betogen daarmee dat vergroening ook commercieel interessant kan zijn voor zakelijke partijen. Dit wordt ook beargumenteerd in een aantal studies waarin de relatie tussen groen en de prijzen op de huizenmarkt in kaart wordt gebracht (zie paragraaf 3.2.5).

Groen speelt ook een rol bij de marketing vanuit projectontwikkelaars. Een illustratie hiervan komt uit het werk van Maruani en Cohen (2013), die advertenties op de woningmarkt hebben geanalyseerd. Wat blijkt: natuur en landschap spelen een belangrijke rol bij het adverteren/promoten van wonen (Maruani en Cohen, 2013). Zij concluderen dan ook dat projectontwikkelaars vaak adverteren met groen om grijs te verkopen. In specifieke zin kan daarom worden ingezoomd op de rol van certificering. Duurzaamheidscertificaten in de bouw en de vastgoedsector kunnen projectontwikkelaars motiveren om bepaalde sociale, milieutechnische en ecologische maatregelen te nemen omdat een certificaat kopers kan aantrekken en goed is voor het imago (Green et al. 2016). Een andere studie laat zien dat deze certificatie de waarde van gebouwen ook kan verhogen, in het geval van dit specifieke groene certificaat met gemiddeld 8,9\% (Bond en Devine, 2015).

\subsection{Investering in en financiering van groen}

\section{De rol van de financiële sector}

De financiële sector, zoals banken en verzekeraars, wordt gezien als een belangrijke aanjager van veranderend landgebruik. Zonder deze sector is stedelijke ontwikkeling in veel gevallen niet mogelijk (Rowley et al., 2014). Een aantal papers wijst de financiële sector dan ook een centrale rol toe in de vele stedelijke ontwikkelingen en bouwprojecten die momenteel plaatsvinden. De banken en andere hypotheekverstrekkers hebben een belangrijke rol in het woonlandschap. De wijze waarop huiseigenaren al dan niet financiering kunnen verkrijgen, is belangrijk voor de manier waar zij investeren in het aanschaffen of renoveren van vastgoed (Chan et al., 2015). Sealey et al. (2018) stellen dat de nadruk op winstmaximalisatie op korte termijn in de huizenmarkt en stadsontwikkeling ten koste gaat van het milieu.

\section{Kosten en baten van groene investeringen}

De kosten en baten van groene investeringen worden in een aantal studies expliciet gemaakt in diverse kosten-batenanalyses. Door het berekenen van de financiële waarde van bepaalde maatregelen kan ook richting planners, projectontwikkelaars en huiseigenaren een beeld van groene maatregelen worden geschetst. Uiteindelijk is van belang hoe de verdeling van de kosten en baten over de verschillende partijen is. In algemene zin vergt het bouwen van duurzame, milieuvriendelijke en groene gebouwen een hogere initiële investering. Daar staat tegenover dat de jaarlijkse kosten lager zijn en het gebouw langer mee kan (Fadaei et al., 2015), hoewel er mogelijk nog kosten samenhangen met beheer van 'levende' groene elementen, zoals planten.

De rendabiliteit van sommige groene investeringen hangt soms nog sterk samen met subsidies of belastingen. Zo berekenen Claus en Rousseau (2012) en Perini en Rosaco (2016) de kosten en opbrengsten van vergroening van daken. In beide studies is dit economisch rendabel, maar niet zonder de aanvullende wet- en regelgeving om deze investeringen mogelijk te maken. Ziogou et al. (2018) stellen dat groendaken economisch gezien nog niet rendabel zijn, maar dat er wel belangrijke baten zijn voor het lokale klimaat.

Het milieu en de klimaatverandering worden soms ook meer gezien als (investerings-)risico: Piccininni (2014) bespreekt de financiële en juridische risico's die deze factoren met zich meebrengen voor huizenbezitters en de vastgoedsector. Dit wordt door hem gebruikt als extra argument voor het realiseren van een groene infrastructuur om deze risico's te beperken. Hoewel ook Green et al. (2016) de financiële meerwaarde van investeringen in groen benoemen, waarschuwen zij wel voor een mogelijk te nauwe focus op de monetaire waarden van groen. Dit zou immers tekort kunnen doen aan een veel breder spectrum aan waarden van groen die niet (gemakkelijk) in geld kunnen worden uitgedrukt. 


\subsection{De integratie van groen en grijs: een zoektocht naar synergieën}

De ontwikkeling van infrastructuur en bebouwing wordt nog vaak vis-à-vis beschikbaar groen besproken, vaak als een soort 'trade-off' waarbij het ene ten koste van het andere gaat. Er is echter lang niet altijd sprake van zo'n trade-off, zoals in sommige papers (impliciet) wordt aangenomen. Steeds meer literatuur legt een link tussen de beide vormen van infrastructuur en biedt een veel meer geïntegreerd perspectief.

\section{Belangrijke debatten}

In conceptuele zin wordt in dit kader diverse terminologie gebruikt: stedelijke groene infrastructuur (Urban Green Infrastructure (UGI)), natuurgebaseerde oplossingen (Nature Based Solutions (NBS)) en bouwen met natuur (Building with Nature) zijn concepten die relateren aan het integreren van groen en grijs. Ook het debat over veerkracht (Resilience) raakt hier sterk aan.

- Stedelijke groene infrastructuur is tegenwoordig een erg populaire term die in veel papers die zijn gevonden in deze review terugkomt. Hierbij wordt vaak op strategisch niveau naar de rol van groen in de stad gekeken en wordt het gehele netwerk van groen en zijn functies in beschouwing genomen, hoewel er ook op specifieke elementen en functies wordt ingezoomd. Ook slaat het concept een brug naar de 'grijze' wereld, waar de term infrastructuur veel gebruikt wordt.

- Natuurgebaseerde oplossingen is een term die al een aantal jaren in opkomst is, maar in de door ons gevonden literatuur slechts sporadisch wordt gebruikt. Grofweg gaat het in de stad vaak om onderzoek waarin men kijkt hoe groen gebruikt kan worden om belangrijke (vaak voorheen grijze) functies te vervullen en daarmee oplossingen voor diverse stedelijke problemen kan bieden.

- Bouwen met natuur gebruikt het (semi-)natuurlijke milieu en landschap als uitgangspunt voor constructie. Het omvat dus een bouwfilosofie waarbij het landschap niet als middel, maar als startpunt dient en functioneel wordt geïntegreerd en gerespecteerd in het ontwerp. Ook deze term komt in de door ons gevonden literatuur slechts sporadisch voor.

- Het debat over veerkracht is veel breder dan natuur alleen, maar in de artikelen die we hebben geïnventariseerd komt het regelmatig naar boven. In die context en terminologie is er het nodige onderzoek over hoe het groene milieu bijdraagt aan de duurzaamheid en bestendigheid van het (grijze) stedelijk milieu en aan de kwaliteit en duurzaamheid van gebouwen. Groen speelt dan ook een belangrijke rol in het huidige debat over veerkracht. Ook de rol van groen in sociale veerkracht, onder andere welzijn en gezondheid, kan door integratie van groen en grijs worden versterkt.

\section{Principes en voorbeelden van integratie}

Een aantal studies richt zich specifiek op de functionele integratie van groen en grijs. Dan wordt bijvoorbeeld gekeken hoe groene elementen bijdragen aan de duurzaamheid van grijs bouwmateriaal of de verbetering van het grijze microklimaat. Er zijn veel leuke voorbeelden van dergelijke 'groengrijsintegratie'. Er is in dit kader de laatste jaren veel aandacht voor groendaken en gevelbegroeiing, en de belangrijke positieve effecten die dit kan opleveren.

Een aantal studies is specifiek gericht op de functionele meerwaarde van groen in/aan/op gebouwen. Zo laten Bonde en Ramirez (2015) zien dat zulke gebouwen beter presteren op het gebied van bijvoorbeeld energieverbruik, wat terugkomt in de prijs. Tiwari en Kumar (2014) laten zien dat groen ook bijdraagt aan het verminderen van corrosie, verwering en erosie van bouwmateriaal. Ook is er aardig wat onderzoek naar de rol van groen in het microklimaat en voor het menselijk comfort. Zowel in het binnen- als buitenmilieu kan groen bijdragen aan temperatuurregulatie en een aangenamere ervaring. Deze groene principes worden tegenwoordig ook vaker in overweging genomen in de architectuur (Boc, 2017; Price et al. 2015; Tiwari en Kumar, 2014).

Een interessant voorbeeld van integratie hangt samen met het beperken van milieurisico's in de verzekeringswereld door het gebruik van groen. Denjean et al. (2017) kijken hoe verzekeraars 
gebruikmaken van groen om het risico op rampen te verkleinen, en ook Piccininni (2014) onderzoekt de rol van groen in het mitigeren van milieurisico's en schadeclaims, met daarbij oog voor de zakelijke kansen die dit biedt.

\section{Principes van duurzaam bouwen}

Een aantal publicaties focust zich in milieutechnische zin op de wijze waarop meer duurzaam en natuurinclusief kan worden gebouwd door de voorwaarden hiervoor te beschrijven of deze principes inhoudelijk uit te werken, bijvoorbeeld rondom 'biopositieve' gebouwen (Zhogoleva en Teryagova, 2017) of 'milieuvriendelijke' gebouwen (Kuzmina et al., 2013). In dergelijke papers wordt vrij specifiek gekeken naar het gebruikte bouwmateriaal. Grofweg focussen deze studies meer op milieu dan echt op natuur, hoewel het een en ander wel met elkaar samenhangt.

De relatie tussen architectuur en biodiversiteit blijft in de literatuur wel een onderbelicht onderwerp. In slechts een klein aantal studies wordt specifiek gekeken naar de relatie tussen de wijze waarop huizen zijn gebouwd en de biodiversiteit. Dit kan gaan over de architectuur van het individuele huis of meer over de manier waarop de 'grijze' wijk als geheel is ontworpen.

\subsection{Planning en governance}

\section{Beleidsinstrumenten}

Hoewel de maatschappelijke opgaven voor de vastgoedsector wel worden benoemd, redeneren veel papers toch vooral vanuit de rol van overheden. De boodschap is niet zelden gericht op de instrumenten die zij kunnen inzetten voor een meer duurzame praktijk in de vastgoedsector. In diverse papers wordt dan ook gekeken hoe overheden/beleidsmakers bepaalde ontwikkelingen kunnen stimuleren via planning en beleid (Mittal en Byahut, 2017; Xu et al., 2018; Votsis, 2017; Moseley et al., 2013; Ma et al., 2013; Lindholm, 2017). Het gaat daarbij om instrumenten zoals nieuwe regelgeving, incentives voor burgers/bedrijven om de leefomgeving te vergroenen, of manieren om investeerders in beweging te krijgen.

Er zijn behoorlijk veel papers die in meer algemene zin op planners zijn gericht en die bepaalde ingrepen of principes aanbevelen. Zo wordt vaak beargumenteerd hoe groene en grijze infrastructuur elkaar kunnen versterken, wat een pleidooi voor groene maatregelen met zich mee kan brengen. Dit zijn vaak papers die pleiten voor bepaalde maatregelen in planning en meer vergroening, maar ook voor sociale waarden. Dit hangt samen met zowel de groene als sociale vraagstukken die hierboven zijn benoemd en met aanbevelingen over de rol en functie van groen in deze vraagstukken. Zo pleiten Lindholm et al. (2017) voor meer betrokkenheid van de vastgoedsector bij het groene milieu.

\section{Governance-vraagstukken}

Een interessant vraagstuk hierbij is wat er gebeurt met braakliggende grond in de stad. Door natuurregelgeving doen projectontwikkelaars volgens Schoukens (2017) nu vaak niets groens met deze brownfields. Ze zijn bang dat als er eenmaal natuurwaarden zijn in een gebied, hun activiteiten kunnen worden belemmerd door natuurwetgeving. Dit verhindert een tijdelijk groene invulling van braakliggend land en vergt goede afspraken en regelgeving om projectontwikkelaars in beweging te krijgen.

Ook natuurcompensatie is een interessant vraagstuk: hoewel de regelgeving in diverse landen sterk verschilt, zijn er vaak verplichte compensatiemaatregelen voor de natuur wanneer een stuk groen door ontwikkeling van bouw of infrastructuur wordt aangetast. Deze maatregelen bieden een belangrijk instrument om groene waarden te beschermen. Een klein aantal studies kijkt naar deze verplichtingen en de wijze waarop hier invulling aan kan worden gegeven. Daarbij laat Peinemann (2016) zien dat compensatie niet altijd plaatsvindt en niet altijd effectief is. 


\subsection{Het perspectief van de bewoner als gebruiker}

\section{Het effect van groen op de huizenprijzen}

Er zijn veel studies waarin de relatie tussen huizenprijzen en de aanwezigheid van groen in de omgeving in kaart wordt gebracht. Vaak wordt hierbij gebruikgemaakt van de hedonischeprijsmethode om de effecten van allerlei variabelen op de huizenprijs te berekenen (Escobedo et al., 2015; Jim en Chen, 2007; Mei et al., 2018; Mittal en Byahut, 2017; Roebeling et al., 2017; Swoboda et al., 2015; Xifilidou et al., 2014). Dergelijke hedonische-prijsstudies, maar ook onderzoek waarin andere methoden worden gebruikt, laten zien dat de aanwezigheid van groen in de omgeving van een huis een belangrijke verklarende variabele is voor de huizenprijzen in diverse landen. Daarmee wordt een (positief) verband gelegd tussen stedelijk groen en de waarde van vastgoed, meestal woonhuizen.

$\mathrm{Er}$ is een aantal artikelen dat specifiek bekijkt wat het effect is van verschillende soorten groen en blauw (Mittal en Byahut, 2017; Czembrowski en Kronenberg, 2016). Uit deze artikelen blijkt dat er ook duidelijke verschillen zijn tussen de diverse soorten groen: parken en bos worden bijvoorbeeld meer gewaardeerd dan kleinschalig groen en begraafplaatsen. Escobedo et al. (2015) betogen dat biodiversiteit an sich weinig doet als het gaat om de prijsimpact van bomen in de omgeving van het huis, maar dat vooral de kroondichtheid van belang is voor het effect van bomen op de huizenprijzen. In enkele gevallen kan de aanwezigheid van groen overigens ook een negatieve invloed hebben op de huizenprijzen: dan gaat het bijvoorbeeld om de aanwezigheid van (voor mensen gevaarlijke) wilde dieren (Broitman et al., 2017) of om begraafplaatsen (Czembrowski en Kronenberg, 2016). Dergelijke negatieve prijseffecten zijn in de literatuur echter betrekkelijk zeldzaam.

Een aantal studies kijkt niet zozeer naar correlaties tussen groen en de huizenprijs, maar richt zich meer op de voorkeuren van bewoners en hun bereidheid om voor groen te betalen. In dit soort willingness to pay-studies laat men zien dat bewoners ook best meer willen betalen voor vastgoed in een groene omgeving (Mell et al., 2016; Xifilidou et al., 2014; Broitman et al., 2017). In onderzoek van Xifilidou et al. (2014) zijn mensen bereid om $2 \%$ meer voor een huis te betalen als de woonomgeving groen is.

\section{Groen en het vestigingsklimaat voor bedrijven}

Hoewel er zeer veel studies zijn gedaan naar de groene voorkeuren van bewoners en het effect van groen op de huizenprijzen, zijn er opvallend weinig studies naar de visie van ondernemers en bedrijven op dit gebied. Bij de keuze van een vestigingslocatie voor bedrijven laten Rymarzak en Siemińska (2012) en Wilkinson et al. (2012) zien dat natuur en milieu wel in het overwegingskader voorkomen, maar dat deze niet altijd een centrale rol spelen in het maken van de uiteindelijke keuze. Bedrijven zijn gemiddeld genomen wel bereid om meer te betalen voor groene kantoorruimten. Met name banken en bedrijven uit de oliesector kiezen vaker voor groene kantoren (Eichholtz et al., 2016).

\section{Sociale vraagstukken en problemen van burgers op de huizenmarkt}

Hoewel deze studie zich niet specifiek richt op bredere sociale vraagstukken die samenhangen met de vastgoedsector, komen deze wel regelmatig naar voren in de door ons verzamelde literatuur. Er is een verschil tussen vraag en aanbod van huizen (Rowley et al., 2014) en in sommige steden is er sprake van een algehele woningnood of gentrificatie waar bepaalde groepen de dupe van zijn (Stouten, 2017). Soms is er vooral sprake van een tekort aan betaalbare of sociale woonvoorzieningen. De toegang tot betaalbare woningen staat onder druk en het leven van vele burgers in sociale huursectoren wordt verstoord doordat er weinig in deze sector wordt geïnvesteerd (Manzo, 2014).

Een prominent sociaal-maatschappelijk debat dat meer specifiek met groen samenhangt, is het debat rondom milieurechtvaardigheid en de (on)gelijke toegang tot groen. Moseley et al. (2013), Haase et al. (2017) en ook anderen bespreken dat er vaak geen gelijke toegang tot groen is in steden. Ook laat werk als dat van Endsley et al. (2018) zien dat toegang tot groen is gecorreleerd met inkomen en dat vooral mensen in rijkere buurten toegang hebben tot groen. De kosten en baten van groen in de stad zijn dus niet gelijk verdeeld, wat leidt tot sociaaleconomische ongelijkheden tussen stedelingen. Haase et al. (2017) laten zien dat vergroening kan leiden tot stijgende huizenprijzen, waardoor oorspronkelijke bewoners uit de wijk verdwijnen en worden vervangen door nieuwe mensen. 


\title{
$4 \quad$ Groen op de (toekomstige) grijze agenda
}

\author{
Groen op de grijze agenda \\ Vanwege de grote invloed die de vastgoedsector heeft op het stedelijke milieu, is de rol van deze \\ sector van groot belang bij het zoeken naar een natuurinclusieve stad die belangrijke diensten levert \\ aan de stedelijke natuur en bevolking. De wetenschappelijke literatuur laat een veelvoud aan \\ perspectieven zien op het speelveld waarbinnen deze zoektocht plaatsvindt en op de manier waarop \\ dit gebeurt. Onze studie van theorie biedt daarbij belangrijke aanknopingspunten in het zoeken naar \\ handelingsperspectieven voor een natuurinclusieve vastgoedsector. Er zijn interessante ideeën en \\ voorbeelden van over de hele wereld, maar een duidelijk 'gouden ei' lijkt nog niet gevonden te zijn. \\ Gezien de grote diversiteit in en complexiteit van stedelijke vraagstukken is het überhaupt de vraag of \\ er wel een gouden ei is. \\ In ons theoretisch kader benoemen we dat praktijken niet zomaar veranderen, maar dat daar een \\ aanleiding voor nodig is. Uiteindelijk zal de rol van groen op de (toekomstige) grijze agenda een \\ belangrijke factor zijn voor de biodiversiteit en natuur in de stad. Het is de vraag of die agenda van \\ kleur zal veranderen. De aandacht vanuit de literatuur lijkt enigszins groeiende, maar het gaat nu nog \\ vooral over milieu en duurzaamheid wanneer men het heeft over groen in de vastgoedsector.
}

Er zijn nog vele uitdagingen en barrières voordat natuurinclusief bouwen een gangbare praktijk zal worden, maar er zijn wel degelijk aanknopingspunten.

\section{Wereldwijde aandacht voor natuur in de stad}

$\mathrm{Er}$ is inmiddels de nodige aandacht voor de relatie tussen de vastgoedsector en biodiversiteit in de stad. Deze aandacht beperkt zich niet tot de Nederlandse of (West)-Europese samenleving: de zoektocht naar literatuur levert ook diverse artikelen uit Oost-Europa, Azië, Australië, Afrika, NoordAmerika en Zuid-Amerika op, waarbij een groot aantal publicaties uit China en Rusland opvalt en er ook publicaties in het Spaans, Duits, Frans, Russisch en Chinees zijn gevonden (die helaas niet konden worden geanalyseerd in deze rapportage).

De ruimtelijke focus van de verzamelde literatuur houdt wel in dat er grote verschillen zijn in context, die samenhangen met de sociale en milieutechnische vraagstukken die spelen in diverse landen. Op deze verschillen is in deze rapportage niet verder ingezoomd. Het is belangrijk om te onthouden dat zaken zoals illegale bebouwing, corruptie, hittestress, parkeerproblemen, aardbevingen, invasieve exoten, smog en wateroverlast niet in alle stedelijke gebieden even sterk spelen. Onze analyse wordt qua context en hoeveelheid artikelen enigszins gedomineerd door westerse literatuur, maar inzichten uit andere delen van de wereld zijn mogelijk ook relevant voor de Nederlandse vastgoedsector.

\section{Meer dan natuur alleen}

Het gaat in de literatuur nog vooral over milieu en duurzaamheid wanneer men het heeft over groen in de vastgoedsector: onze zoektocht leverde veel meer milieugerelateerde artikelen op dan publicaties die echt over natuur of biodiversiteit in de stad gaan. Gedacht kan dan worden aan artikelen over bijvoorbeeld energieverbruik, waterverbruik, milieuvriendelijk bouwen en het tegengaan van milieuvervuiling. Onze literatuurreview laat daarmee zien dat milieuzaken rondom duurzaamheid in de vastgoedsector veel duidelijker op de wetenschappelijke agenda staan dan natuurkwesties. De scheidslijn tussen natuur- en milieuartikelen is echter niet zwart-wit: er zijn ook publicaties waarin natuur en milieu als deel van een groter geheel worden gezien en gezamenlijk of in relatie tot elkaar worden besproken.

Hoewel natuur geen dominant thema is als het gaat over verduurzaming van de vastgoedsector, is er dus wel degelijk wetenschappelijke aandacht voor het onderwerp. En hoewel we geen harde uitspraken kunnen doen, hebben we op basis van onze literatuurstudie en ervaringen in de samenleving het gevoel dat deze aandacht de laatste jaren groeiende is. Eerder onderzoek laat zien 
dat partijen in de vastgoedsector zich ook bewust zijn van vraagstukken op het gebied van natuur en biodiversiteit binnen hun sector (Dijkshoorn-Dekker et al., 2018).

\section{Vervolgstappen}

In het vervolgonderzoek op deze rapportage zullen we verder ingaan op handelingsperspectief voor de vastgoedsector. Dit vervolgonderzoek vindt plaats in de vorm van een brede enquête onder vastgoedpartijen in Nederland, een verdiepend casusonderzoek naar voorbeelden van natuurinclusief bouwen en het bieden van handelingsperspectief. Met dit onderzoek beogen we om bij te dragen aan een betere vertegenwoordiging van de sociaaleconomische en ecologische waarden van groen in het afwegingskader van de vastgoedsector. 


\section{Literatuur en websites}

Aalbers, C., D.A., K., Langers, F., 2018. Bedrijfs- en burgerinitiatieven in stedelijke natuur: hun succesfactoren en knelpunten en hoe de lokale overheid ze kan helpen slagen. Wageningen University and Research.

Aalbers, C.B.E.M., Sehested, K., 2018. Critical upscaling. How citizens' initiatives can contribute to a transition in governance and quality of urban greenspace. Urban Forestry and Urban Greening 29, 261-275.

Ajzen, I. (1991). The theory of planned behaviour. Organizational Behaviour and Human Decision Processes, 50(2), 179-211.

Arts, B., Behagel, J., Bommel, S.v., Koning, J.d., Turnhout, E., 2012. Prelude to Practice: Introducing a Practice Based Approach to Forest and Nature Governance, in: Arts, B., Behagel, J., Bommel, S.v., Koning, J.d., Turnhout, E. (Eds.), Forest and Nature Governance. A Practice Based Approach. Springer, Dordrecht.

Arts, B., Behagel, J., Van Bommel, S., De Koning, J., Turnhout, E., 2013. Forest and Nature Governance - a practice based approach. Springer, Dordrecht.

Arvola, A., Vassallo, M., Dean, M., Lampila, P., Saba, A., Lähteenmäki, L., et al (2008). Predicting intentions to purchase organic food: The role of affective and moral attitudes in the theory of planned behaviour. Appetite, 50(2-3), 443-454.

Battisti, F., Guarini, M.R., Chiovitti, A., 2017. The assessment of real estate initiatives to be included in the socially-responsible funds. Sustainability (Switzerland) 9.

Behagel, J., 2012. The politics of democratic governance. Wageningen University, Wageningen, p. 223.

Boc, V.I., 2017. Introducing the bioclimatic security concept in green infrastructure planning and design, Acta Horticulturae, 1189 ed. International Society for Horticultural Science (ISHS), Leuven, Belgium, pp. 235-240.

Bond, S.A., Devine, A., 2016. Certification Matters: Is Green Talk Cheap Talk? The Journal of Real Estate Finance and Economics 52, 117-140.

Bonde, M., Ramirez, J., 2015. A post-occupancy evaluation of a green rated and conventional oncampus residence hall. International Journal of Sustainable Built Environment 4, 400-408.

Broitman, D., Czamanski, D., Toger, M., 2017. The complex interactions between cities and nature. Quality Innovation Prosperity 21, 92-105.

Browne, A., Medd, W., Anderson, B., Pullinger, M., 2014. Method as intervention: Intervening in practice through quantitative and mixed methodologies, Social Practices, Intervention and Sustainability: Beyond Behaviour Change. Taylor and Francis Inc., pp. 179-195.

Bruijn GJ. de, Kroeze W., Oenema A., Brug J. (2008). Saturated fat consumption and the Theory of Planned Behaviour: Additive and interaction effects of habit strength. Appetite 51, 318-323.

Buijs, A., Mattijssen, T.J.M., Van der Jagt, A.P.N., Ambrose-Oji, B., Andersson, E., Elands, B., H.M., Steen Møller, M., 2016. Active citizenship and the resilience of urban green: fostering the diversity and dynamics of citizen contributions through mosaic governance. Current Opinion on Environmental Sustainability 22, 1-6.

Burton, M., Dempsey, N., Mathers, A., 2014. Connecting making and keeping: Design and management in place-keeping, Place-Keeping: Open Space Management in Practice, pp. 125-150.

Cameron, R.W.F., Blanuša, T., Taylor, J.E., Salisbury, A., Halstead, A.J., Henricot, B., Thompson, K., 2012. The domestic garden - Its contribution to urban green infrastructure. Urban Forestry and Urban Greening 11, 129-137.

Chan, S., Haughwout, A., Tracy, J., 2015. How Mortgage Finance Affects the Urban Landscape, Handbook of Regional and Urban Economics, pp. 987-1045.

Cinderby, S., Bagwell, S., 2018. Exploring the co-benefits of urban green infrastructure improvements for businesses and workers' wellbeing. Area 50, 126-135.

Claus, K., Rousseau, S., 2012. Public versus private incentives to invest in green roofs: A cost benefit analysis for Flanders. Urban Forestry and Urban Greening 11, 417-425.

Coolen, H., Meesters, J., 2012. Private and public green spaces: Meaningful but different settings. Journal of Housing and the Built Environment 27, 49-67. 
Czembrowski, P., Kronenberg, J., 2016. Hedonic pricing and different urban green space types and sizes: Insights into the discussion on valuing ecosystem services. Landscape and Urban Planning 146, 11-19.

Denjean, B., Denjean, B., Altamirano, M.A., Graveline, N., Giordano, R., Van der Keur, P., Moncoulon, D., Weinberg, J., Máñez Costa, M., Kozinc, Z., Mulligan, M., Pengal, P., Matthews, J., van Cauwenbergh, N., López Gunn, E., Bresch, D.N., Denjean, B., 2017. Natural Assurance Scheme: A level playing field framework for Green-Grey infrastructure development. Environmental Research 159, 24-38.

Dijkshoorn-Dekker, M.W.C.; Blaeij, A.T. de; Polman, N.B.P.; Michels, R.; Ballemans, M., 2014. Wijzer met groen in de stad. Van bestaansvoorwaarde naar verdienmodel. Den Haag: LEI Wageningen UR.

Dijkshoorn-Dekker, M., van Haaster-de Winter, M., Mattijssen, T., \& Polman, N. (2019). Inspiratie voor een leefbare stad. (Publicatie / Wageningen Economic Research: 2019-092). Wageningen: Wageningen Economic Research. https://edepot.wur.nl/503655

Dijkshoorn-Dekker, M., Kortstee, H., Michels, R., Polman, N., 2018. Groen in de stad - het perspectief van de vastgoedsector. Wageningen University \& Research, Den Haag, p. 38. https://edepot.wur.nl/455202

Dijkshoorn-Dekker, M.W.C., Soma, K., de Blaeij, A.T., 2017. Groene initiatieven in de stad; Handelingsperspectief provincies voor het stimuleren van maatschappelijke betrokkenheid bij groen in de stad. Wageningen Economic Research, Wageningen.

Dijkshoorn-Dekker, M.W.C., van Leeuwen, E., Kortstee, H., Michels, R., Polman, N., 2019. Het perspectief van de vastgoedsector op groen. Service magazine 26: 08-01-2019.

Dijkshoorn-Dekker, M.W.C., Kortstee, H., Mattijssen, T.J.M., Haaster-De Winter, M., Polman, N., de Rooij, S., Steingrover, E., 2020. De transitie naar een natuurinclusieve stad; Breng de vastgoedsector in beweging. Wageningen Economic Research, Den Haag. https://edepot.wur. nl/522462

Dobson, S., Jorgensen, A., 2015. Increasing the resilience and adaptive capacity of cities through entrepreneurial urbanism. International Journal of Globalisation and Small Business 6, 149-162.

Eichholtz, P.M.A., Kok, N., Quigley, J.M., 2016. Ecological Responsiveness and Corporate Real Estate. Business and Society 55, 330-360.

Elmqvist, T., Setälä, H., Handel, S.N., van der Ploeg, S., Aronson, J., Blignaut, J.N., GómezBaggethun, E., Nowak, D.J., Kronenberg, J., de Groot, R., 2015. Benefits of restoring ecosystem services in urban areas. Current Opinion in Environmental Sustainability 14, 101-108.

Elmqvist, T., Siri, J., Andersson, E., Anderson, P., Bai, X., Das, P.K., Gatere, T., Gonzalez, A., Goodness, J., Handel, S.N., Hermansson Török, E., Kavonic, J., Kronenberg, J., Lindgren, E., Maddox, D., Maher, R., Mbow, C., McPhearson, T., Mulligan, J., Nordenson, G., Spires, M., Stenkula, U., Takeuchi, K., Vogel, C., 2018. Urban tinkering. Sustainability Science 13, 15491564.

Endsley, K.A., Brown, D.G., Bruch, E., 2018. Housing Market Activity is Associated with Disparities in Urban and Metropolitan Vegetation. Ecosystems, 1-15.

Escobedo, F.J., Adams, D.C., Timilsina, N., 2015. Urban forest structure effects on property value. Ecosystem Services 12, 209-217.

Fadaei, S., Iulo, L.D., Yoshida, J., 2015. Architecture: A Missing Piece in Real-estate Studies of Sustainable Houses, Procedia Engineering, pp. 813-818.

Frantzeskaki, N., Dumitru, A., Anguelovski, I., Avelino, F., Bach, M., Best, B., Binder, C., Barnes, J., Carrus, G., Egermann, M., Haxeltine, A., Moore, M.-L., Mira, R.G., Loorbach, D., Uzzell, D., Omann, I., Olsson, P., Silvestri, G., Stedman, R., Wittmayer, J., Durrant, R., Rauschmayer, F., 2016. Elucidating the changing roles of civil society in urban sustainability transitions. Current Opinion in Environmental Sustainability 22, 41-50.

Fu, J., Xiao, G., Wu, C., 2017. Urban Green Transition: Conceptual Change and Stakeholder Involvement in Depth. Procedia Engineering 198, 781-789.

Fuller, R.A., Irvine, K.N., Devine-Wright, P., Warren, P.H., Gaston K, J., 2007. Psychological benefits of greenspace increase with biodiversity. Biology letters 2007, 390 - 394.

Geels, F., 2002. Technological transitions as evolutionary configuration processes: A multi-level perspective and a case-study. Research policy, 31(8/9), 1257-1274.

Geels, F.W., 2011. The multi-level perspective on sustainability transitions: Responses to seven criticisms. Environmental Innovation and Societal Transitions 1, 24-40. 
Geels, F.W., Schot, J., 2007. Typology of sociotechnical transition pathways. Research Policy 36, 399-417.

Grafakos, S., Gianoli, A., Tsatsou, A., 2016. Towards the development of an integrated sustainability and resilience benefits assessment framework of urban green growth interventions. Sustainability (Switzerland) 8.

Green, T.L., Kronenberg, J., Andersson, E., Elmqvist, T., Gómez-Baggethun, E., 2016. Insurance Value of Green Infrastructure in and Around Cities. Ecosystems 19, 1051-1063.

Grin, J., 2010. Understanding transitions from a governance perspective, in: Rotmans, J., Schot, J., Grin, J. (Eds.), Transitions to sustainable development. New direction in the study of long term transformative change. Routledge, London, pp. 223-319.

Haase, D., Frantzeskaki, N., Elmqvist, T., 2014. Ecosystem services in urban landscapes: Practical applications and governance implications. Ambio 43, 407-412.

Haase, D., Kabisch, S., Haase, A., Andersson, E., Banzhaf, E., Baró, F., Brenck, M., Fischer, L.K., Frantzeskaki, N., Kabisch, N., Krellenberg, K., Kremer, P., Kronenberg, J., Larondelle, N., Mathey, J., Pauleit, S., Ring, I., Rink, D., Schwarz, N., Wolff, M., 2017. Greening cities - To be socially inclusive? About the alleged paradox of society and ecology in cities. Habitat International 64, 41-48.

Hargraeves, T., 2011. Practice-ing behaviour change: Applying social practice theory to proenvironmental behaviour change. Journal of consumer Culture 11(1) 79-99.

Hargreaves, T., Longhurst, N., Seyfang, G., 2013. Up, down, round and round: Connecting regimes and practices in innovation for sustainability. Environment and Planning A 45, 402-420.

Hussain, M.R.M., Tukiman, I., Zen, I.H., 2014. Landscape design as an added value to real estate development in Klang Valley, Advanced Materials Research. Trans Tech Publications, pp. 281-284.

Ignatieva, M., Ahrné, K., 2013. Biodiverse green infrastructure for the 21st century: from "green desert" of lawns to biophilic cities. Journal of Architecture and Urbanism 37, 1-9.

Jim, C.Y., Chen, W.Y., 2007. Consumption preferences and environmental externalities: A hedonic analysis of the housing market in Guangzhou. Geoforum 38, 414-431.

Kabisch, N., 2015. Ecosystem service implementation and governance challenges in urban green space planning - The case of Berlin, Germany. Land Use Policy 42, 557-567.

Kahneman, D. (2011). Ons feilbare denken. Thinking, fast and slow. Business Contact, Amsterdam.Kuindersma, W., Boonstra, F.G., 2010. The changing role of the state in dutch regional partnerships. Environ. Plann. C Gov. Policy 28, 1045-1062.

Kuzmina, G.V., Abzhalelov, B.B., Kuzhamberdieva, S.Z., Zhumagulov, T.Z., 2013. Ecology of residential buildings of Kyzylorda city. Middle East Journal of Scientific Research 16, 423-427.

Lindholm, G., 2017. The implementation of green infrastructure: Relating a general concept to context and site. Sustainability (Switzerland) 9.

Littig, B., Leitner, M., 2017. Combining Methods in Practice Oriented Research - A Multi-method Case Study on Sustainable Cohousing, in: Jonas, M., Littig, B., Wroblewski, A. (Eds.), Methodological Reflections on Practice Oriented Theories. Springer International Publishing, Cham, pp. $161-176$.

Loorbach, D., 2010. Transition management for sustainable development: A prescriptive, complexitybased governance framework. Governance 23, 161-183.

Ma, M., Liu, D., Wang, L., 2013. Ecology thinking based on old city renovation, Applied Mechanics and Materials, pp. 2535-2538.

Manzo, L.C., 2014. On uncertain ground: being at home in the context of public housing redevelopment. International Journal of Housing Policy 14, 389-410.

Maruani, T., Amit-Cohen, I., 2013. Marketing landscapes: The use of landscape values in advertisements of development projects. Landscape and Urban Planning 114, 92-101.

Mattijssen, T.J.M., Arts, B.J.M., Buijs, A.E., Elands, B.H.M., van Dam, R.I., Donders, J.L.M., 2019. The transformative potential of active citizenship: understanding changes in local governance practices. Sustainability 11 .

Mei, Y., Zhao, X., Lin, L., Gao, L., 2018. Capitalization of urban green vegetation in a housing market with poor environmental quality: Evidence from Beijing. Journal of Urban Planning and Development 144.

Mell, I.C., Henneberry, J., Hehl-Lange, S., Keskin, B., 2016. To green or not to green: Establishing the economic value of green infrastructure investments in The Wicker, Sheffield. Urban Forestry and Urban Greening 18, 257-267. 
Mittal, J., Byahut, S., 2017. Scenic landscapes, visual accessibility and premium values in a single family housing market: A spatial hedonic approach. Environment and Planning B: Urban Analytics and City Science.

Moseley, D., Marzano, M., Chetcuti, J., Watts, K., 2013. Green networks for people: Application of a functional approach to support the planning and management of greenspace. Landscape and Urban Planning 116, 1-12.

Ollongren, K.H., 2018. Woonagenda en regiogesprekken, in: Woningmarkt, D. (Ed.), The Hague.

Ollongren, K.H., 2019. Integrale visie op de woningmarkt, 17 september 2019. Ministerie van Binnenlandse Zaken en Koninkrijksrelaties, Den Haag.

Peinemann, C., 2016. Management of Ecological Compensation Measures, Contributions to Economics. Physica-Verlag, pp. 273-287.

Perini, K., Rosasco, P., 2016. Is greening the building envelope economically sustainable? An analysis to evaluate the advantages of economy of scope of vertical greening systems and green roofs. Urban Forestry \& Urban Greening 20, 328-337.

Phenton, J., 2013. The impact of car culture on our urban landscape: How shoppers have literally been driven off the British high street. Housing, Care and Support 16, 161-166.

Piccininni, F., 2014. The evolving "nature" of environmental risk: A responsible approach for residential and commercial real estate. Environmental Claims Journal 26, 308-318.

Ponizy, L., Majchrzak, W., Zwierzchowska, I., 2017. Cultural Ecosystem Services of Urban Green Spaces-Supply and Demand in The Densely Built-Up Areas. Poznan Old Town Case Study. IOP Conference Series: Earth and Environmental Science 95, 052009.

Poppe, K.J., Termeer, C., Slingerland, M., 2009. Transitions towards sustainable agriculture and food chains in peri-urban areas. Wageningen Academic Publishers, Wageningen, the Netherlands.

Price, A., Jones, E.C., Jefferson, F., 2015. Vertical Greenery Systems as a Strategy in Urban Heat Island Mitigation. Water, Air, \& Soil Pollution 226, 247.

Priess, P., Rajnoha, R., Losert, S., Vogel, S., Teufel, H., 2017. Sustainable real estate development and its implications on investment: Statistical relations on the case from austria. Journal of Security and Sustainability Issues 6, 419-434.

Rauschmayer, F., Bauler, T., Schäpke, N., 2015. Towards a thick understanding of sustainability transitions - Linking transition management, capabilities and social practices. Ecological Economics 109, 211-221.

Raymond, C.M., Frantzeskaki, N., Kabisch, N., Berry, P., Breil, M., Nita, M.R., Geneletti, D., Calfapietra, C., 2017. A framework for assessing and implementing the co-benefits of naturebased solutions in urban areas. Environmental Science and Policy 77, 15-24.

Reckwitz, A., 2002. Towards a Theory of Social Practices. A Development in Culturalist Theorizing. European Journal of Social Theory 5, 243-263.

Rip, A., Kemp, R., 1998. Technological change, in: Rayner, S., Malone, E. (Eds.), Human Choices and Climate Change 2. Battelle, Colombus, Ohio, pp. 327-399.

Roebeling, P., Saraiva, M., Palla, A., Gnecco, I., Teotónio, C., Fidelis, T., Martins, F., Alves, H., Rocha, J., 2017. Assessing the socio-economic impacts of green/blue space, urban residential and road infrastructure projects in the Confluence (Lyon): a hedonic pricing simulation approach. $\mathrm{J}$. Environ. Plann. Manage. 60, 482-499.

Røpke, I., 2009. Theories of practice - New inspiration for ecological economic studies on consumption. Ecological Economics 68, 2490-2497.

Rowley, S., Costello, G., Higgins, D., Phibbs, P., 2014. The financing of residential development in Australia. AHURI Final Report, 1-84.

Rymarzak, M., Siemińska, E., 2012. Factors affecting the location of real estate. Journal of Corporate Real Estate 14, 214-225.

Simon, H.A., 1982. Models of bounded rationality. Cambridge, MA: MIT Press.

Schatzki, T., 2010. The timespace of human activity: on performance, society, and history as indeterminate teleological events. Lexington Books., Lanham, MD

Schatzki, T., 2012. A primer on practices., in: Higgs, J., Barnett, R., Billett, S., Hutchings, M., Trede, F. (Eds.), Practice-Based Education. Perspectives and Strategies. Sense Publishers, Rotterdam, the Netherlands, pp. 13-27.

Schoukens, H., 2017. Reconciliation ecology in practice: Legal and policy considerations when implementing temporary nature on undeveloped lands in the European Union. Land Use Policy 67, 178-189. 
Schwartz-Shea, P., Yanow, D., 2012. Interpretive Research Design: Concepts and Processes. Routledge, New York \& London, 186 pp.

Sealey, K.S., Binder, P.M., Burch, R.K., 2018. Financial credit drives urban land-use change in the United States. Anthropocene 21, 42-51.

Shove, E., Pantzar, M., Watson, M., 2012. The dynamics of social practice: everyday life and how it changes. Sage Publications, London.

Shove, E., Spurling, N., 2013. Sustainable practices - social theory and climate change. Routledge, London and New York, 220 pp.

Shove, E., Walker, G., 2010. Governing transitions in the sustainability of everyday life. Research Policy 39, 471-476.

Simmons, R., Krokfors, K., 2015. Scandinavian housing design since the mid 1990s: Selected lessons from practice. Built Environment 41, 305-324.

Sovacool, B., Hess, D., 2017. Ordering theories: Typologies and conceptual frameworks for sociotechnical change.

Spangenberg, J.H., Lorek. S., 2019. Suffiency and consumer behaviour: from theory to policy. EnergyFpolicy 129: 1070-1079.

Stouten, P., 2017. Gentrification and urban design in the urban fabric of Rotterdam. Journal of Urban Regeneration and Renewal 11, 92-103.

Swoboda, A., Nega, T., Timm, M., 2015. Hedonic analysis over time and space: The case of house prices and traffic noise. Journal of Regional Science 55, 644-670.

Tiwary, A., Kumar, P., 2014. Impact evaluation of green-grey infrastructure interaction on built-space integrity: An emerging perspective to urban ecosystem service. Science of the Total Environment 487, 350-360.

Toxopeus, H., Polzin, F., 2017. Characterizing nature-based solutions from a business model and financing perspective. Utrecht University, Utrecht.

Trowbridge, M.J., Pickell, S.G., Pyke, C.R., Jutte, D.P., 2014. Building healthy communities: Establishing health and wellness metrics for use within the real estate industry. Health Affairs 33, 1923-1929.

Van Dam, R., Mattijssen, T.J.M., Buijs, A.E., Vader, J., Donders, J.L.M., 2016. De betekenis van groene zelf-governance: analyse van verschillende vormen van dynamiek in de praktijk, Wettelijke Onderzoekstaken Natuur en Milieu. Wageningen University \& research, Wageningen.

Van der Jagt, A.P.N., Elands, B.H.M., Ambrose-Oji, B., Gerőházi, E., Steen Møller, M., 2016. Participatory governance of urban green space: trends and practices in the EU. Nordic Journal of Architectural research 28 .

Van Haaster-de Winter, M.A., Dijkshoorn-Dekker, M.W.C., Mattijssen, T.J.M., Polman, N.B.P., Kortstee, H., 2020. Natuurinclusief bouwen: wat beweegt de Nederlandse vastgoedsector? Onderzoek naar motieven, barrières en gedrag in de transitie naar meer groen. Wageningen Economic Research, Wageningen. https://doi.org/10.18174/522641

Vanags, J., Butane, I., 2013. Major aspects of development of sustainable investment environment in real estate industry, Procedia Engineering, pp. 1223-1229.

Votsis, A., 2017. Planning for green infrastructure: The spatial effects of parks, forests, and fields on Helsinki's apartment prices. Ecological Economics 132, 279-289.

Watson, M., 2012. How theories of practice can inform transition to a decarbonised transport system. Journal of Transport Geography 24, 488-496.

Wilkinson, S., Karhu, J., Laitala, A., Falkenbach, H., Sarasoja, A.L., 2012. The green preferences of commercial tenants in Helsinki. Journal of Corporate Real Estate 14, 50-62.

Wood, W. en D.T. Neal (2009). The habitual consumer. Journal of Consumer Psycology, 19, 579-592.

Xifilidou, A., Vagiona, D., Karanikolas, N., 2014. Estimating the willingness to pay of Thessaloniki's residents for the increase of the green spaces and exploring its effects to the real Estate Values. Fresenius Environmental Bulletin 23, 2750-2754.

Xu, C., Haase, D., Pauleit, S., 2018. The impact of different urban dynamics on green space availability: A multiple scenario modeling approach for the region of Munich, Germany. Ecological Indicators 93, 1-12.

Yuling, C., 2017. The expansion of cities and the ensuing limitations on the production of space. Sotsiologicheskie Issledovaniya 2017-January, 107-115.

Zhogoleva, A., Teryagova, A., 2017. On methods of sustainable architectural design of bio-positive buildings in the low-rise residential development structure. 
Ziogou, I., Michopoulos, A., Voulgari, V., Zachariadis, T., 2018. Implementation of green roof technology in residential buildings and neighborhoods of Cyprus. Sustainable Cities and Society 40, 233-243. 


\section{Bijlage 1 Literatuuronderzoek}

Als deel van dit project is in de internationale wetenschappelijke literatuur gezocht naar aanknopingspunten en inzichten rondom de rol van groen in de vastgoedsector.

\section{Werkwijze literatuurstudie}

Om een overzicht van de wetenschappelijke stand van zaken te verkrijgen, is voor dit project een systematische literatuurreview uitgevoerd. Tijdens deze review is ten eerste gezocht naar wetenschappelijke artikelen over zowel de vastgoedsector als over 'groen'. Op basis hiervan werd vervolgens een handmatige selectie gemaakt van mogelijk relevante artikelen. Deze zijn opgenomen in een database, waarna ze verder zijn bestudeerd en uitgewerkt tot de in dit rapport gepresenteerde analyse.

\section{Dataverzameling}

Het zoeken naar relevante artikelen is in twee stappen uitgevoerd. Bij de eerste en belangrijkste stap is gebruikgemaakt van de database Scopus, waarin een groot aantal wetenschappelijke artikelen is opgenomen. In deze database is met diverse zoekopdrachten gezocht in de titel, het abstract en de kernwoorden van wetenschappelijke publicaties. Hiervoor zijn diverse zoekopdrachten geformuleerd die uit twee delen bestonden: een deel met 'groene' zoektermen en een 'vastgoed'-deel. Om opgenomen te kunnen worden in de resultaten moesten woorden uit beide delen voorkomen in de doorzochte publicaties.

Als aanvullende tweede stap is specifieker naar artikelen gezocht in een aantal vooraanstaande wetenschappelijke tijdschriften. Ten eerste is in vier vooraanstaande wetenschappelijke tijdschriften op het gebied van 'stedelijk groen' gezocht naar artikelen over vastgoed. Daarnaast is in acht vooraanstaande wetenschappelijke tijdschriften op het gebied van vastgoed gezocht naar artikelen over natuur en landschap.

De door ons gebruikte zoekmethoden leverden een eerste 'sample' van zeven- tot tienduizend artikelen op. Een exact aantal is lastig te geven, omdat veel artikelen in meerdere zoekresultaten voorkwamen. Om de analyse behapbaar en actueel te houden, is besloten om uitsluitend te focussen op artikelen die zijn gepubliceerd vanaf het jaar 2012. Ook is de zoektocht beperkt tot de voor ons onderzoek relevante vakgebieden, wat inhoudt dat artikelen uit wetenschappelijke domeinen zoals wiskunde, scheikunde, geneeskunde en computerwetenschappen zijn uitgesloten. Na deze stappen bleef er nog een sample over van grofweg drie- tot vierduizend artikelen. Al deze artikelen zijn door de onderzoekers handmatig 'gescand' om een inschatting te kunnen maken van de relevantie voor ons onderzoek. Dit hield in dat op basis van titel, tijdschrift en wetenschappelijke discipline werd ingeschat of het artikel relevant zou kunnen zijn. Als tweede stap is bij mogelijk relevante artikelen het abstract bekeken, wat uiteindelijk leidde tot een definitieve selectielijst met relevante artikelen.

\section{Analyse van artikelen}

Op basis van de lijst met definitief geselecteerde artikelen is een database opgebouwd. Een twintigtal artikelen viel in dit stadium nog af, omdat de onderzoekers geen toegang hadden tot de volledige tekst, of omdat alleen het abstract in het Engels was geschreven en de rest in een vreemde taal (vaak Spaans of Russisch). Daardoor zijn er uiteindelijk 86 artikelen meegenomen in deze review. In de gemaakte database zijn digitale versies van al deze artikelen opgenomen.

Hierna werd een document opgesteld waarin van elk artikel het abstract is opgenomen. De betreffende artikelen zijn vervolgens bestudeerd door de onderzoekers, die bij elk abstract aantekeningen maakten om de relevantie bevindingen van het artikel te beschrijven. Dit document diende vervolgens als uitgangspunt voor de literatuuranalyse in deze rapportage. Daarvoor werden de relevante bevindingen van de artikelen kort samengevat en daarna geclusterd onder diverse thema's. Op basis hiervan werd een lijst van punten opgesteld, die vervolgens verder werd uitgewerkt aan de 
hand van de betreffende artikelen. Dit gebeurde door middel van een kwalitatieve, interpretatieve analyse in een iteratief proces, waarbij diverse onderzoekers meerdere keren met elkaar sparden om de resultaten goed te kunnen duiden.

\section{Zoekproces}

- "real estate" AND "urban green" (19 hits)

- "real estate" AND landscape (404 hits)

- "real estate sector" AND green (15 hits)

- "real estate sector" AND nature (21 hits)

- realty AND nature (29 hits)

- realty AND landscape (8 hits)

- "real estate" AND nature (712 hits)

- (housing OR houses) AND (urban OR City) AND (nature OR landscape) (3971 hits)

- "green-grey" OR "green/grey" OR "green grey" AND integration OR infrastructure (14 hits)

- "urban green" OR nature OR landscape AND "project developer*" (41 hits)

- "nature inclusive" OR "nature-inclusive" (8 hits)

- "building with nature" (47 hits)

- "green-grey" OR "green/grey" OR " green grey" AND housing OR construction OR neighbourhood OR planning (16 hits)

- "estate market" AND landscape OR nature OR "urban green" OR "green space" (171 hits)

- "real estate" AND ecolog* (298 hits)

- "architecture" AND "urban green" or "green space" (190 hits)

- bioarchitectur* (33 hits)

- "biomimicry" AND "real estate" or "urban development" (0 hits)

- "business climate" AND nature OR landscape OR "urban green" (36 hits)

- "climate for business" AND nature OR landscape OR "urban green" (1 hit)

- "establishment environment" AND nature OR landscape OR "urban green" (2 hits)

- "business environment" AND nature OR landscape OR "urban green" (873 hits)

- "establishment climate" AND nature OR landscape OR "urban green" (0 hits)

- investment AND nature OR landscape OR "urban green" AND urban OR city OR metropolitan (1353 hits)

- "infrastructur* develop*" AND city OR urban OR metropolitan AND nature OR landscape OR "urban green" (267 hits)

Wetenschappelijke tijdschriften

In de volgende 'urban green' wetenschappelijke tijdschriften werd gezocht met de query 'real estate'

OR 'realty', waarna op basis van titel en eventueel abstract werd besloten of het artikel relevant was:

- Landscape and urban Planning (315 hits)

- Urban Forestry and Urban Greening (66 hits)

- Environment and urbanization (140 hits)

- Urban ecosystems (51 hits)

In de volgende 'real estate' wetenschappelijke tijdschriften werd gezocht met de query 'nature' OR 'landscape', waarna op basis van titel en eventueel abstract werd besloten of het artikel relevant was:

- Journal of Real Estate Research, Journal of Real Estate Portfolio Management, Journal of Housing Research, Journal of Real Estate Literature, Journal of Sustainable Real Estate, Journal of Real Estate Practice and Education (gecombineerde query bij alle American Real Estate Society journals) (59 hits, gezocht via abstracts)

- Journal of Real Estate Finance and Economics (672 hits)

- Journal of Urban economics (808 hits) 
Wageningen Economic Research Postbus 29703

2502 LS Den Haag

T 0703358330

Ecommunications.ssg@wur.nl

www.wur.nl/economic-research

Wageningen Economic Research RAPPORT

2020-013b
De missie van Wageningen University \& Research is 'To explore the potential of nature to improve the quality of life'. Binnen Wageningen University \& Research bundelen Wageningen University en gespecialiseerde onderzoeksinstituten van Stichting Wageningen Research hun krachten om bij te dragen aan de oplossing van belangrijke vragen in het domein van gezonde voeding en leefomgeving. Met ongeveer 30 vestigingen, 5.000 medewerkers en 12.000 studenten behoort Wageningen University \& Research wereldwijd tot de aansprekende kennisinstellingen binnen haar domein. De integrale benadering van de vraagstukken en de samenwerking tussen verschillende disciplines vormen het hart van de unieke Wageningen aanpak. 



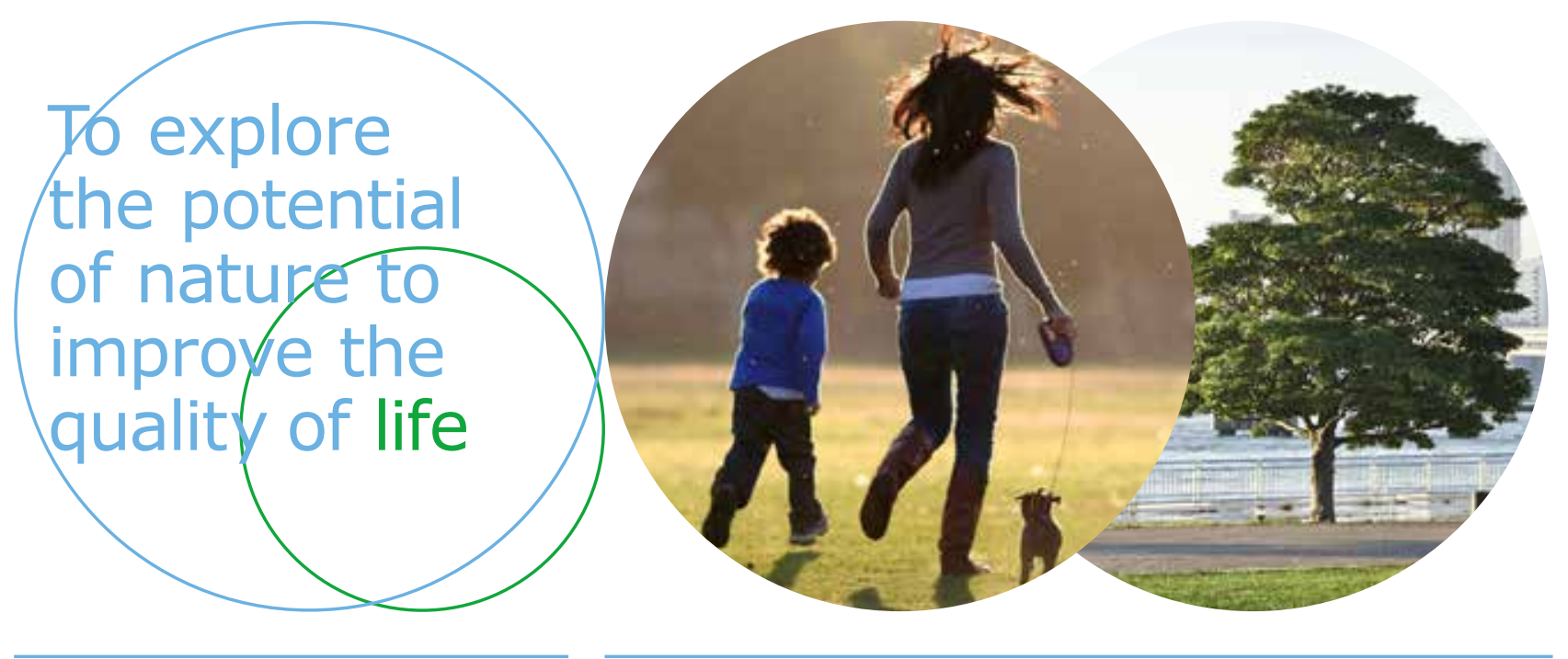

Wageningen Economic Research Postbus 29703

2502 LS Den Haag

T 0703358330

E communications.ssg@wur.nl www.wur.nl/economic-research

Rapport 2020-013b

ISBN 978-94-6395-400-6
De missie van Wageningen University \& Research is 'To explore the potential of nature to improve the quality of life'. Binnen Wageningen University \& Research bundelen Wageningen University en gespecialiseerde onderzoeksinstituten van Stichting Wageningen Research hun krachten om bij te dragen aan de oplossing van belangrijke vragen in het domein van gezonde voeding en leefomgeving. Met ongeveer 30 vestigingen, 5.000 medewerkers en 12.000 studenten behoort Wageningen University \& Research wereldwijd tot de aansprekende kennisinstellingen binnen haar domein. De integrale benadering van de vraagstukken en de samenwerking tussen verschillende disciplines vormen het hart van de unieke Wageningen aanpak. 